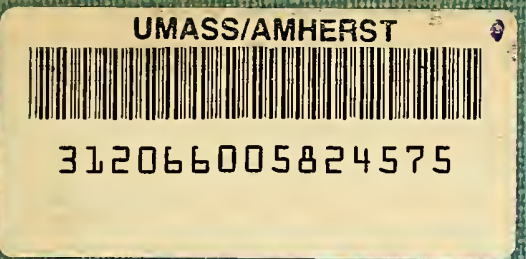

. 


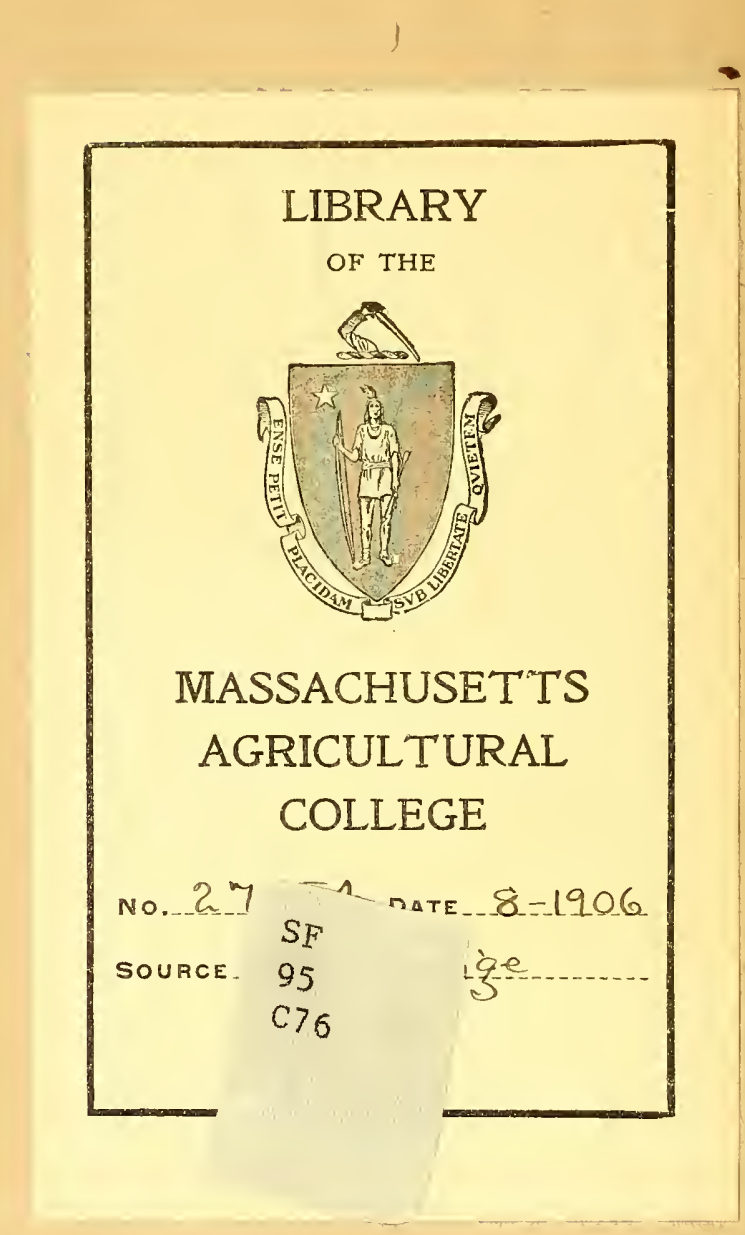


This book may be kept out

\section{TWO WEEKS}

only and is subject to a fine of THO CENTS a day thereafter.

It will be due on the day indicated below.

\section{MAR 21962}

\section{CARO}




$$
\begin{aligned}
& 636.07 \\
& C 87
\end{aligned}
$$




\section{Meat, Milk and Money}

How to produce the latte: by increasing the former.

BY

WM. G. CROCKER

Manager Feed Department

\section{WASHBURN-CROSBY CO.}

Minneapolis "Buffalo Louisville St. Louis

COPYRIGHT, 1904

Washburn - Crosby Co.

U. S. A. 


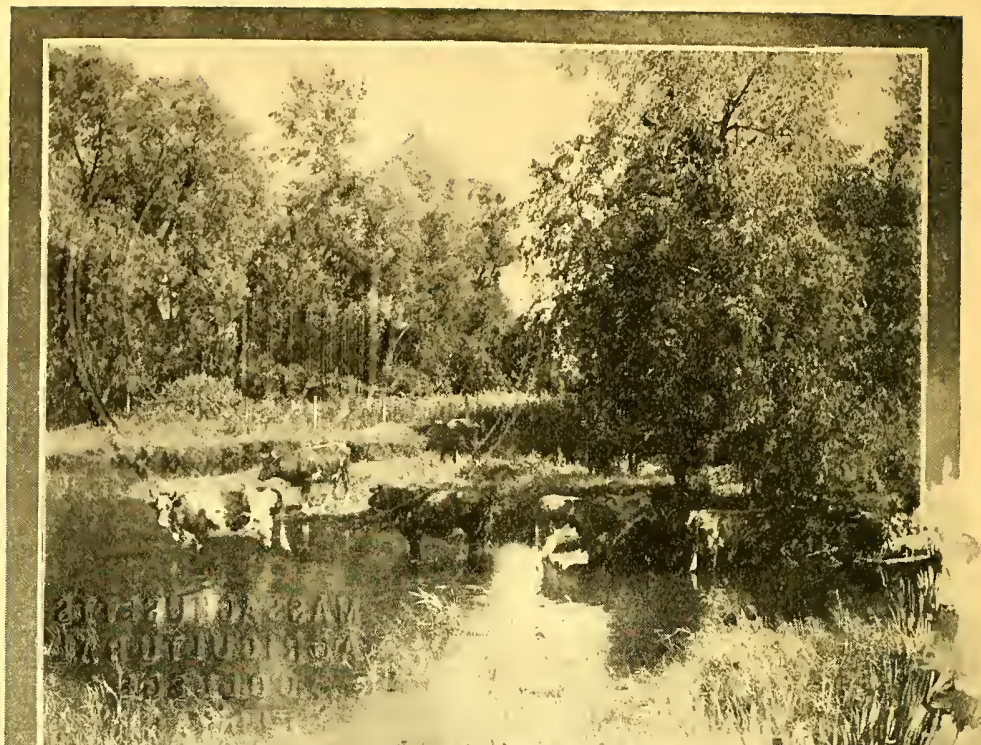
i.

The Cow
THERE is nothing very twet title, but think of wlyat we whild do without her and we would quickly cliange Richard III.'s exclamation to: "A cow, a cow, my kingdom for a cow:"

From time immemorial the good old faithful cow has been an object of interest and necessity. In Bible times, long before the Christian Era, we read of the herds of different ones, and. so on down until the present period. But as time has progressed, so indeed has the study of economic principles, affecting the breeding and raising of cattle, especially during the past generation.

The United States Census Bureau shows that in 1900 there were 17,13.5, 6333 dairy cows in this country. Each one of these cows is in reality a milk factory. Like all other manufacturing enterprises, the great desire is to produce the largest output at the least expense, and right here is where 
scientific research enters the arena. There are cows and cows, good, bad and indifferent; fancy stock, common and scrubs. Even the latter can be made a paying proposition when treated on a business basis. In addition to the above number of dairy corvs, the 1900 Census Report showed that there were $35,268,195$ other cattle, and including calves and stock under two years old, the grand total was $69,335,832$ neat cattle, valued at $\$ 1,516,307,270$. From this it is evident that the cow is the basis of a very important industry, not only for the production of milk, but also for that of beef.

NA'TURE has been very good and considerate to man and beast. As there are great varieties of necessities and 1uxuries for the one, there is, indeed, a wide scope for the other. But no one would for a moment contend that a man could exist always on fruit cake, or even potatoes; so a cow would have a hard time of it on a Food diet of simply corn and hay. The man might (and probably would) subsist for a time; but think of the indigestion. Of course the cow could live, but she would not give full value received. If you are not, therefore making a study of the economic feeding of your cow or your herd, please read this through and then get to thinking.

We want you to know more about Wheat Mill Feed; buy more of it; use more of it. You will say that our motive is a selfish one. If it is, we gire you full measure and running over for your money. 


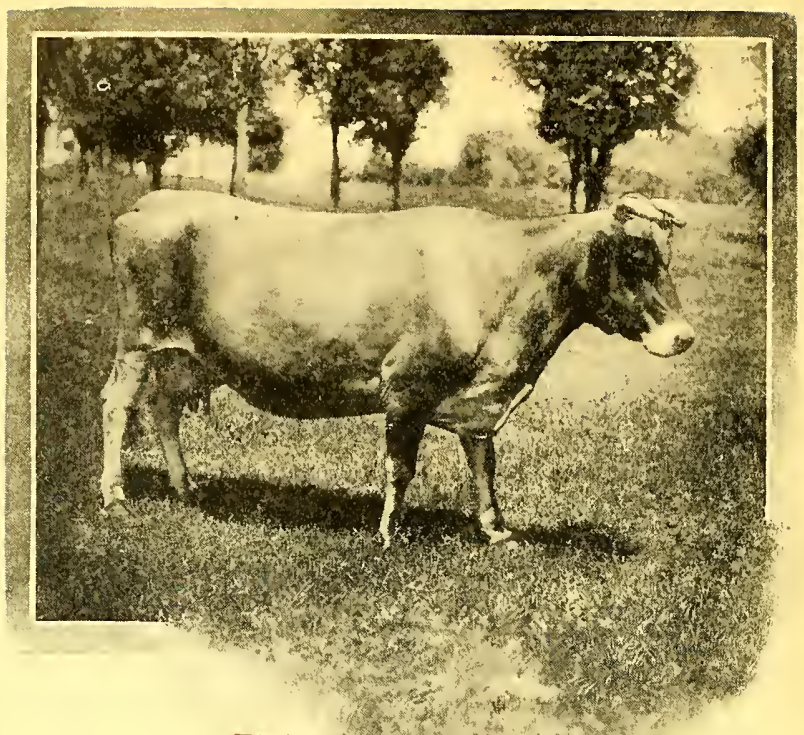

THE versatile Tom Moore spoke well when he said: "As we journey through life let us live by the way." This can indeed be construed very broadly and extended to all walks of life. Everything which we can do to make life easier; to bring greater comforts with least exertion; to reduce the every-day drudgeries to a minimum; to The give us the best results at the least exMan pense - this makes "living by the way," because it enables us to get more out of life.

But what has this to do with Mill-feed? Simply this: That by the use of wheat Offals the Feeder, the Dairyman or the Farmer can secure the best results from his herds. To do without these products is the worst kind of false economy. There is no more honorable or independent vocation than Farming, Dairying or Stock Raising, but the chances are that not one out of ten thousand interested in these lines is in business for his health. Like all humanity, he is after the great American. Dollar. He is not working from sunrise to sunset every 
day in the week and eviery week in the year except to put dollars in the bank, or to buy comforts for his family or himself. The constant desire is to get more dollars, and the best way to get them is to feed more Wheat Bran and Middlings. This is a bold assertion, but it is the honest truth, supported by arguments and experiments actually too numerous to mention.

W

ITH the introduction of Agricultural Experiment Stations in nearly every State in the Union, and the development of scientific research, the splendid merits The of wheat by-products have been, and are being more and more fully recognized and their use agitated and urged. Wheat Bran is to-day the best stock-food on the market, and we beg to call your attention to a few tables and statements of eminent authorities on this subject.

We wish every farmer and feeder in the country could orvn and would peruse carefully a copy of Prof. W. A. Henry's comprehensive work entitled "Feeds and Feeding."

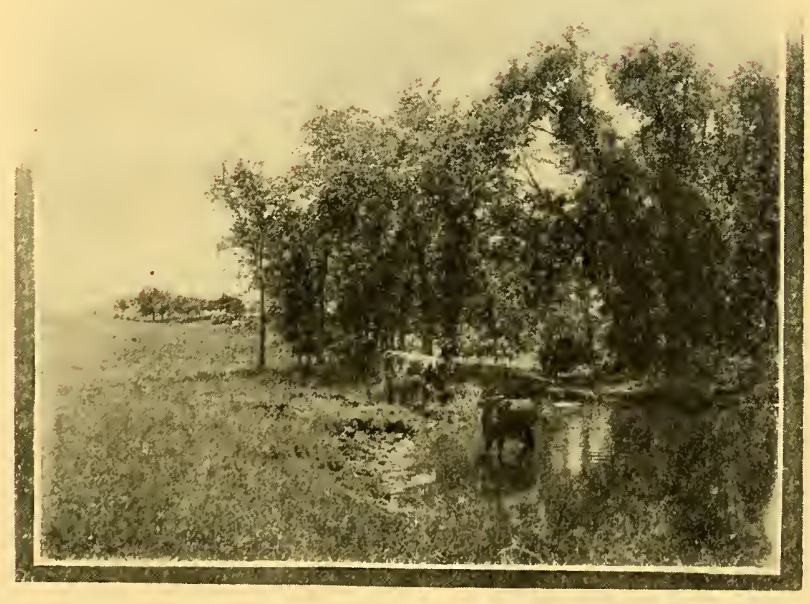




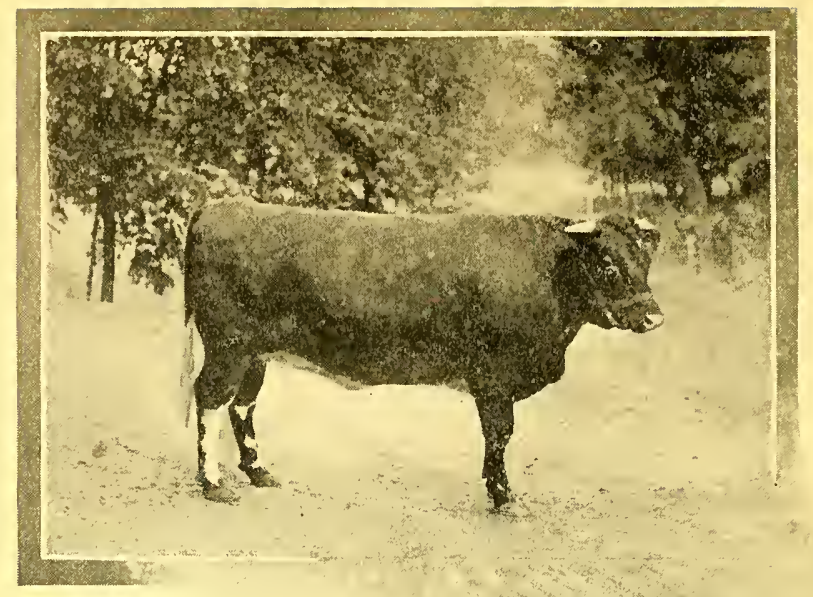

Nearly twenty years ago the millers of Minneapolis issued a pamphlet on the subject of Wheat Bran under the title of "How to Make Beef." We doubt if we could do better to-day than to have it reprinted and circulated widely. In this Prof. Henry was quoted freely, and among other things said:

A few

words from Prof. W. A. Henry

"Food for man or beast can be divided into three classes; first protein or albumen, second carbohydrates, third fat. We can make them simply two classes, because fat serves the same function in digestion as the carbohydrates."

"Protein is that which goes to make muscle or the lean meat of the body. The white of an egg is almost pure protein; bran and oil meals are rich in protein."

"Sugar and starch are almost pure carbohydrates, while the fiber of hay, straw and stalks belong to the same list. In protein we have the same elements, with the addition of one more element that we have in carbohydrates. We have for a carbohydrate the three elenents, carbon, hydrogen and oxygen, three gases which in a plant may 
combine and produce carboly-drates. Now in protein there is one more element necessary; if you hare carbon, hydrogen and oxygen and add nitrogen, you will have protein. Now, nitrogen is the negative element. It is nitrogen that gets into all our wonderful explosives, in nitro-glycerine, and all these explosive compounds. It is not only tricky in explosions, but easily changes its relations with other elements. Nitrogen is not only the basic structure of these compounds that I have spoken of, but it is the expensive part of our food. Eggs, lean meat, cheese, bran, oil meal; food for man or beast, rich in nitrogen, are expensive as compared with corn stalks, hay, straw, starch, sugar beets, turnips or vegetables which lack nitrogen, or contain it in small quantities only."

Everyone knows that raising wheat takes the fertility out of the soil, and for the time being this is all very well for the virgin farms of the west, but in time this strength must be returned to the ground in some manner, and we naturally turn to fertilizers.

\section{Protein}

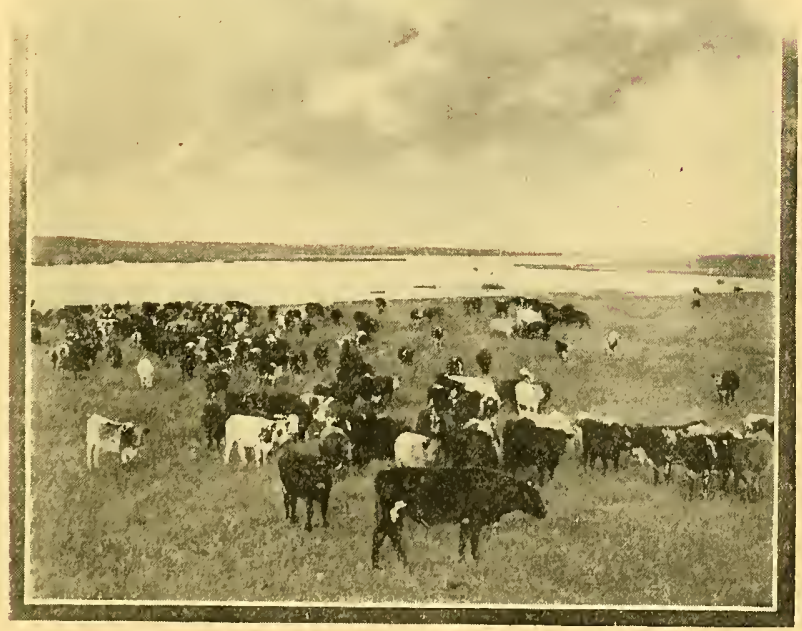




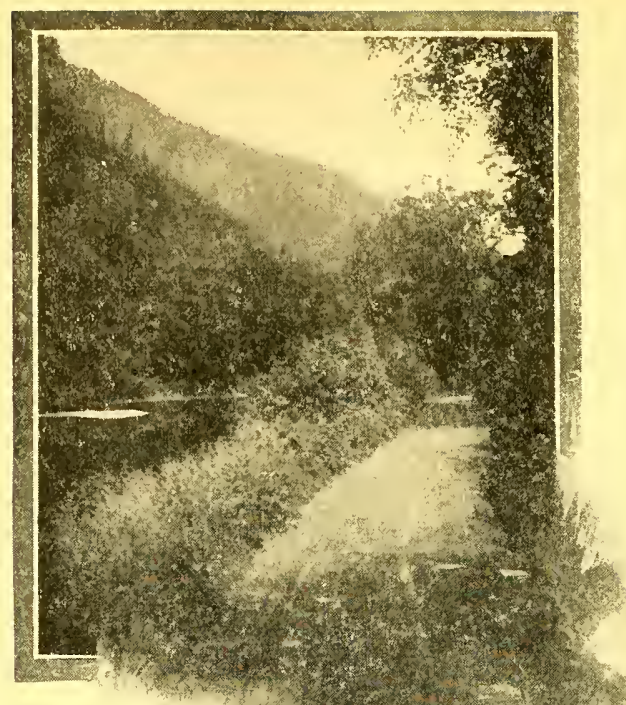

A vercentage of protein is found in the outside, or Bran, of the wheat kernel. It is the protein that comes from the soil and contains the nitrogen, therefore the fertilizing quality of the wheat. Starch has little value as a fertilizer. As Prof. Henry said further:

"Now, starch is not manure. If you put a ton of starch on the ground it wouldn't be worth a cent as a fertilizer. It is only mineral substances like lime, phosphates and potash that are of value. There is a little

The fertility, of course, in the wheat straw, but Wheat most of it is stored up in the outside of the Berry wheat grain, so when you have sold your wheat and the miller gives you back the. Bran, you have sold very little of value so far as the fertility of your land is concerned."

The common farm products, corn-starch, corn-stalks and even Indian corn itself are rich in carbohydrates, but deficient in protein; therefore, to equalize his rations the feeder must buy protein foods, and Wheat Bran slould be the first choice. 


\section{AGRICULTURAL EXPERIMEN'T STATION COMMENTS.}

PLEASE note the following from bulIetins issued by various Agricultural Experiment Stations:

The valuable ingredients in animal foods are ash or mineral matter, protein, fat and a class of compounds called carbohydrates, of which starch, sugar and crude fiber are the most important examples. Although the ash or mineral matter is essential to the well being of the animal, it is abundantly supplied by most materials one is likely to feed, so what one most needs to consider in buying and using cattle foods are protein, fat and carbohydrates.

A suficient supply of protein in the food is indispensable. The working animal depends upon it to replenish and repair its working machinery, the growing animal to make muscle and build up its whole system, the sheep to make wool and the mileh cowe to make the casein and albumen of its milk. No other substance ean take its place, or be manufactured into protcin by the body.-Maine Bulletin No. 80 .

The most valuable constituent of a feeding stuff, from the standpoint of the purchaser, is protein.Iaine Bulletin No. I02.

The

Necessity

of

Protein

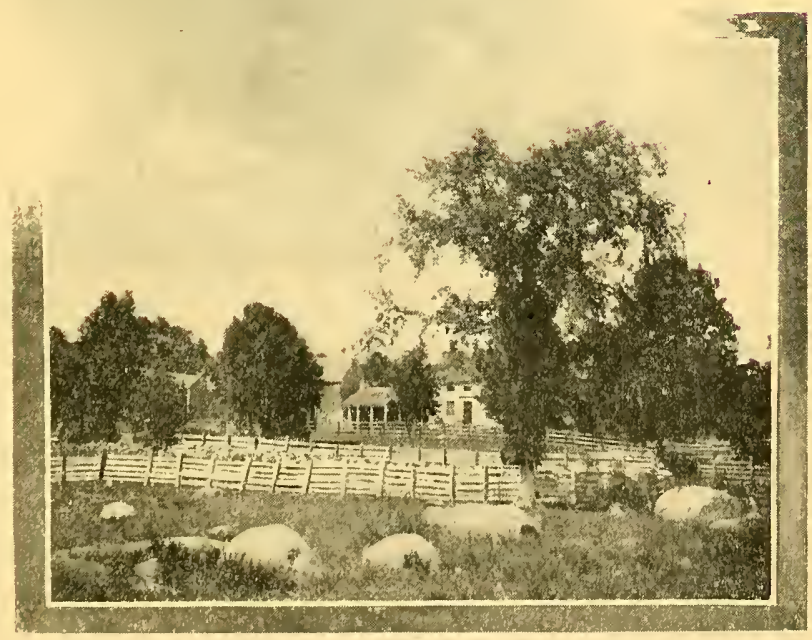




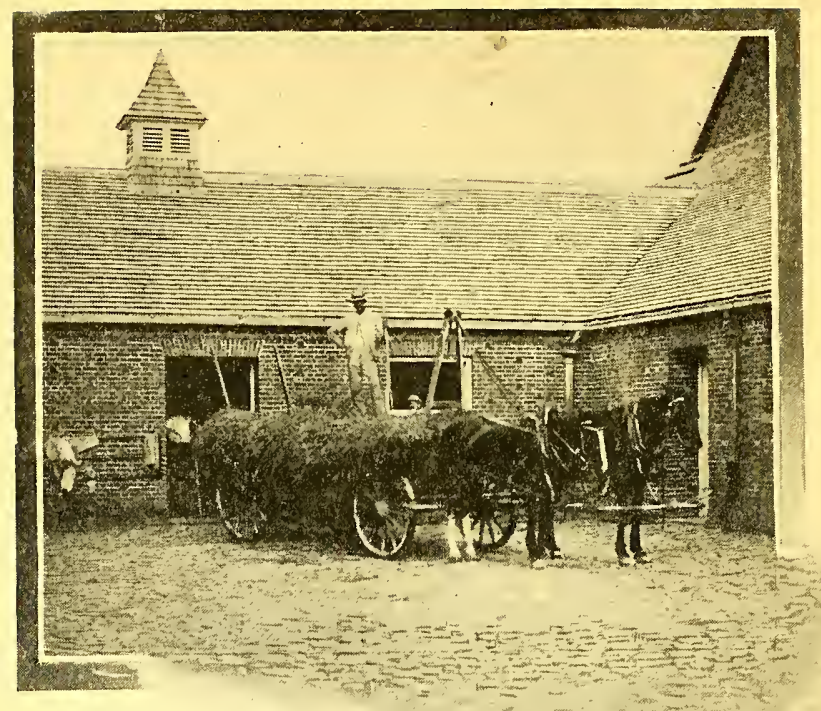

\section{MANURIAL VALUE.}

The mineral constituents in the following table have been compiled from "The Fertility of the Land." The amounts given, of water, ash, nitrogen, phosphoric acid and potash, are for one thousand pounds of fceds:

ELEAENTS CF FERTILTTY IN I,DOO LES.

\begin{tabular}{|c|c|c|c|c|c|c|c|c|}
\hline & & 若 & 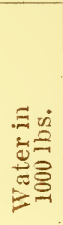 & 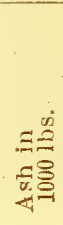 & 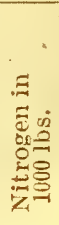 & 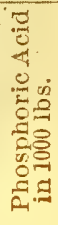 & 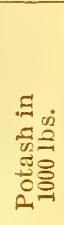 & 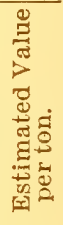 \\
\hline & $\begin{array}{l}\text { Carrots............. } \\
\text { Corn silage, green } \\
\text { Beets, sugar....... } \\
\text { Mangel-wurzel.... } \\
\text { Wheat straw...... } \\
\text { Potatoes........... }\end{array}$ & $\begin{array}{r}63 \\
6 \mathrm{~S} \\
80 \\
197\end{array}$ & $\begin{array}{l}870 \\
779 \\
820 \\
873 \\
136 \\
750\end{array}$ & $\begin{array}{l}10 \\
8.1 \\
12.2 \\
53.0 \\
11 .\end{array}$ & $\begin{array}{l}1.2 \\
1.7 \\
1.7 \\
.64 \\
1.4\end{array}$ & $\begin{array}{r}.9 \\
1.9 \\
.9 \\
.9 \\
1.2\end{array}$ & $\begin{array}{l}2.5 \\
3.7 \\
3.7 \\
3.8 \\
6.3 \\
5.7\end{array}$ & $\begin{array}{r}\$ .65 \\
.82 \\
.88 \\
.90 \\
.94 \\
1.04\end{array}$ \\
\hline The & $\begin{array}{l}\text { Brower's grains, } \\
\text { wet............... } \\
\text { Oat straw........ }\end{array}$ & $\begin{array}{r}158 \\
55\end{array}$ & $\begin{array}{l}762 \\
145\end{array}$ & $\begin{array}{l}12.4 \\
57 .\end{array}$ & $\begin{array}{l}6.2 \\
1.9\end{array}$ & $\begin{array}{l}4.2 \\
2.8\end{array}$ & 17.7 & $\begin{array}{l}2.16 \\
2.38\end{array}$ \\
\hline $\begin{array}{l}\text { Fertility } \\
\text { of the } \\
\text { Land }\end{array}$ & 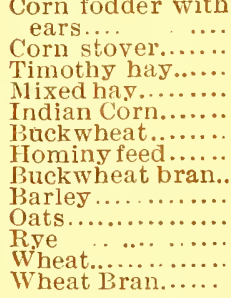 & $\begin{array}{r}69 \\
393 \\
149 \\
20 \\
5 \\
1128 \\
560 \\
257 \\
1358 \\
93\end{array}$ & $\begin{array}{r}92 \\
150 \\
143 \\
137 \\
130 \\
1+1 \\
89 \\
156 \\
113 \\
133 \\
134 \\
134 \\
132\end{array}$ & $\begin{array}{l}37.4 \\
45.3 \\
41.1 \\
61.5 \\
14.8 \\
27.7 \\
22.1 \\
28 . \\
21.8 \\
31.0 \\
19.8 \\
17.1 \\
58.0\end{array}$ & $\begin{array}{r}4.0 \\
2.7 \\
4.4 \\
9.9 \\
12.6 \\
12.3 \\
12.0 \\
11.8 \\
13.9 \\
14.7 \\
15.8 \\
16.3 \\
19.5\end{array}$ & $\begin{array}{r}2.9 \\
3.8 \\
5.0 \\
4.1 \\
5.7 \\
6.9 \\
9.8 \\
4.2 \\
7.9 \\
6.9 \\
8.6 \\
8.7 \\
26.9\end{array}$ & $\begin{array}{r}14.0 \\
11.4 \\
14.1 \\
13.2 \\
3.7 \\
3.0 \\
4.9 \\
12.7 \\
4.8 \\
4.8 \\
5.8 \\
5.5 \\
15.2\end{array}$ & $\begin{array}{l}2.64 \\
2.57 \\
2.95 \\
4.33 \\
4.31 \\
4.34 \\
4.68 \\
4.82 \\
5.04 \\
5.16 \\
5.72 \\
5.84 \\
9.24\end{array}$ \\
\hline
\end{tabular}

-From Ithaca Bulletin No. 154. 
The intelligent buyer of feeding stufis who has his barns well filled with hay, corn fodder and silage will have very little use for these feeds low in protein content.-Maine Bulletin No. 80.

Purchasers are advised, however, to give the preference to those articles branded with the names of reputable manufacturers or to examine the article closely before buying in order to note the quality.Massachusetts, Hatch Bulletin No. 78.

There is so much profit in selling ground corn cobs and broom corn at the price of wheat bran, that the consumer must ever be on the watch against this fraud. The safest thing is to buy only well known, reliable brands of this class of goods. If consumers will see to it that all of this class of feeds which they buy carries the name of the miller, there will be little likelihood of their being defrauded.-Maine Bulletin No. 92.

It is poor economy for the farmer to purchase starchy feeds, since he can produce them more economically.-Massachusetts, Hatch Bulletin No. 93.

Bran from our flouring mills makes the ideal grain dairy feed. It is obtainable in almost all sections, is good combined with other grains and comes nearest to making a stccessful ration of any grain fed alone. It is a safe feed when used in large rations and continuously.

From our experience we find a mixture of bran and corn better when the animals are on full feed. The proportion averaging best is about 3 parts bran to 2 parts ground corn. If the animal is too fat the proportion of corn should be reduced. In summer when on pasture and it is desired to feed a small amount of grain, we found bran alone to average better than a mixture of corn and bran.-Kentucky Bulletin No. 106.

On the other hand, bran is bought not simply as a desirable bulky and laxative food, but especially because, on account of its percentage of protein being much higher than that of corn, the nutritive ratio of an ordinary mixed food may be narroweủ by its use. The digestion experiments compiled by Lindsey (Report of Massachusetts Agricultural Experiment Station I896), while too few to be conclusive, nevertheless indicate an appreciably higher digestibility for the protein of spring wheat bran. Furthermore, existing analyses indicate that spring wheat is, on the average, one per cent richer in protein than are the winter varieties. In all wheat the

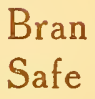




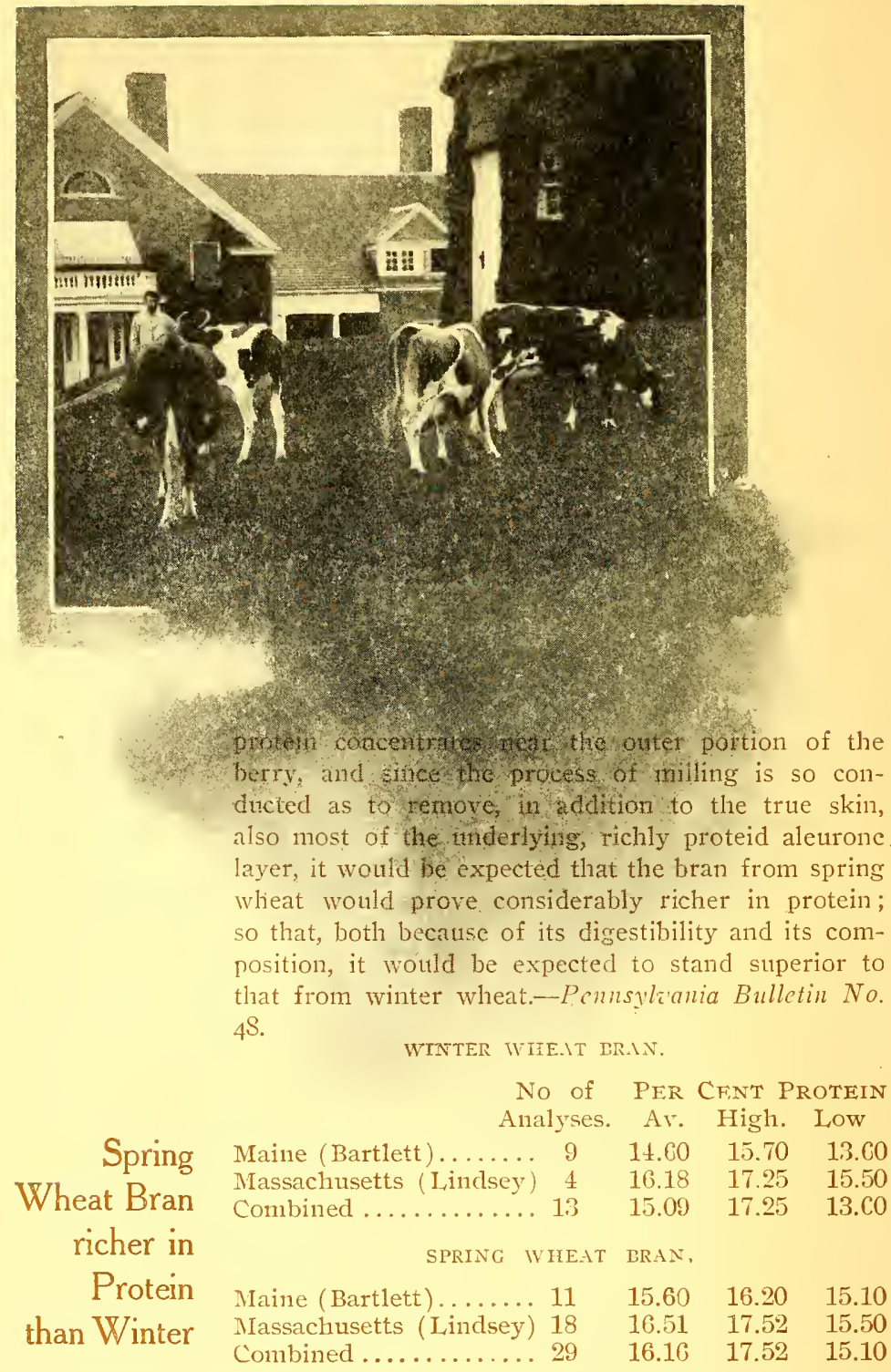

Grouping all figures for protein, 33 analyses of winter brans show I5.I4 per cent, and 58 analyses of spring brans show 16.23 per cent.

These data lead clearly to this conclusion:

That, on the average, despite the higher market price, winter bran furnishes a smaller quantity of nitrogenous nutrients to the animal because of its inferiority in composition, and, possibly, of its lower digestibility.-Pennsyliania Billetin No. 48 . 
One of the finest farms in this country is that of Mr. Hamilton McL. Twombly of New York City-Florham Farms at Madison, N. J., under the very able management of Mr. J. L. Hope, who writes us as follows under date of April I5th, 1904:

Of all the cereal by-products, wheat bran is the one I should like the least to be without. I consider it indispensable in the rearing of dairy calves and as the main feature in the ration for cows around calving time. Its laxative properties and palatability make it especially desirable and incline one to give it a preference over everything else.

Outside of its value as determined by analysis, it performs a useful part in giving added bulk to the heavy concentrated feeds like cotton-seed and oil meals, and rendering the latter much more safe to feed.

Figures talk, so look at the following records of two cows belonging to Mr. Twombly's herd:

The World's Year's Butter fat Record Broken.

Guernsey Cow, Imp. Charmante of the Gron 1.4442, Adv. R. It Makes Official Record from Oct. II, 1902, to Oct. IO, I903, of $11,874.76$ lbs. Milk, 676.46 lbs. Butter-fat.

Charmante of the Gron, No. 14442, was imported by Mr. H. McK. Twombly in 1 gor from the herd of Mr. E. A. Hambro of Kent, England. She was dropped July 7,1896 , and is registered on the Island as 3944 P. S., R. G. A. S. Her sire is His Majestyr 952 P. S., R. G. A. S., and her dam was Cliarmante 5th, 2619 P. S., R. G. A. S., known in England as McCharmante 48 ço E. G. H. B. She was bred by Mr. J. Bourgaize, Gron, St. Savior's, Guernsey. Charmante of the Gron is a very well marked cow, of good dairy conformation, with excellent udder, and a great credit to the breed and to $\mathrm{Mr}$. Twombly's choice herd. She dropped a bull calf Oct. 6, 1502 , and he is developing into an animal of much promise, and is known as Florham King, No. 840r.

Her year's record began Oct. II, 1902, and the requirements for her admission to The Advanced Register were 10,000 lbs. milk: 360 lbs. butter-fat. The results of hor year's work are as follows:

\section{Figures}

\section{Unimpeach- able Testimony}




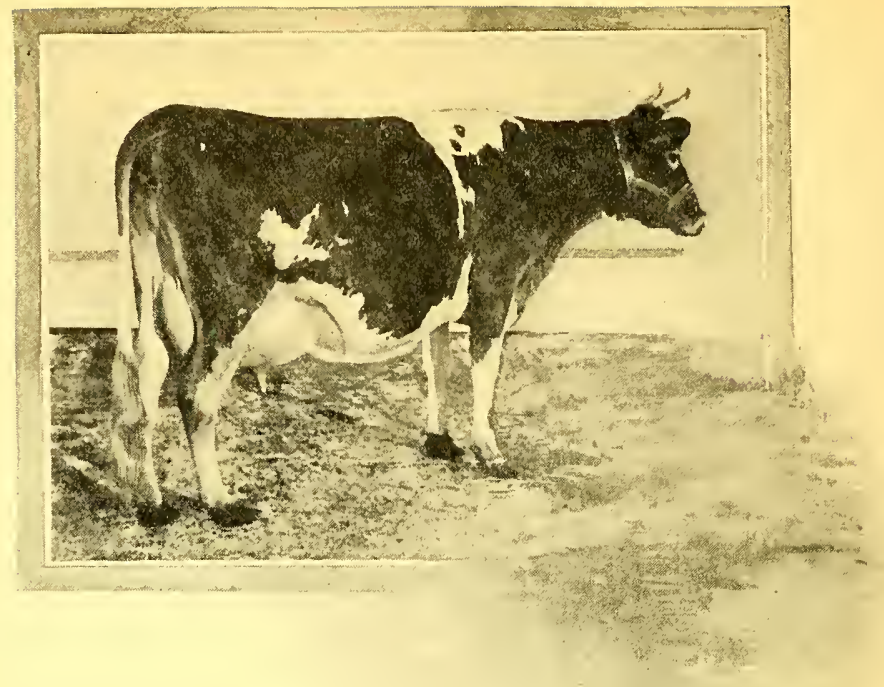

IMP. CHARMANTE OF THE GRON.

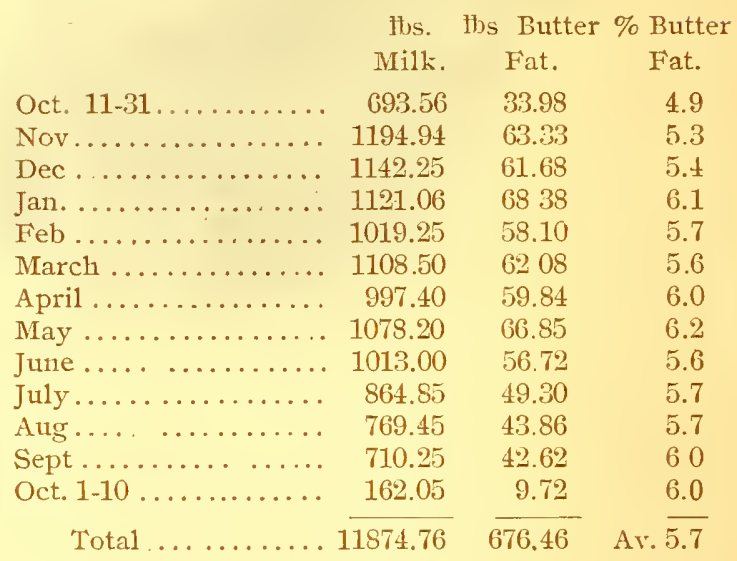

This record was supervised in connection with the New Jersey Agricultural Experiment Station. Not Not only docs the work of the year greatly exceed Guess the requirements of the Register, but it is the best Wear's record of a cow of any breed in the world, Work where public supervision has been given same. It is equivalent to $7 \$ 9.2$ lbs. of butter, or an average of 2.16 lbs. of butter a day. 
Mr. J. L. Hope, the able superintendent of Mr. Twombly's Florham Farms, gives the following data as to the feed consumed by the cow during the year:

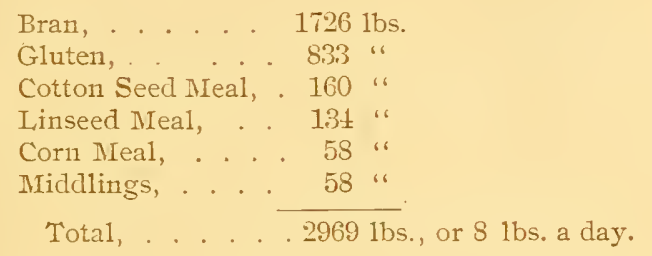

For roughage she had corn ensilage, beets or mangels and mixed hay in winter. In summer, in addition to pasturage, she had in season, oats and peas, green clover, alfalfa and corn fodder.

This record is certainly a credit to the cow and her owncr, and to the careful management which Mr. Hope has given her.-The Herd Register and Brecder's Journal.

Year's Record of Imp. Pretoria,

No. 14443. Adv: R. 73.

II,528.84 1bs. Milk; 595.35 lbs Butter-fat.

Among the many good cows at Florham Farms, owned by Mr. H. M[cK. Twombly at Madison, N. J., is the cow, Imported Pretoria I4443, which was registered on the Island as R. G. A. S. 4416 P. S. She was bred by J. G. Browning of St. Martin's Farish, being dropped Jan. I2th, I 808 . Her sire was Moderator 105 I P. S., and dam May Lady 3rd

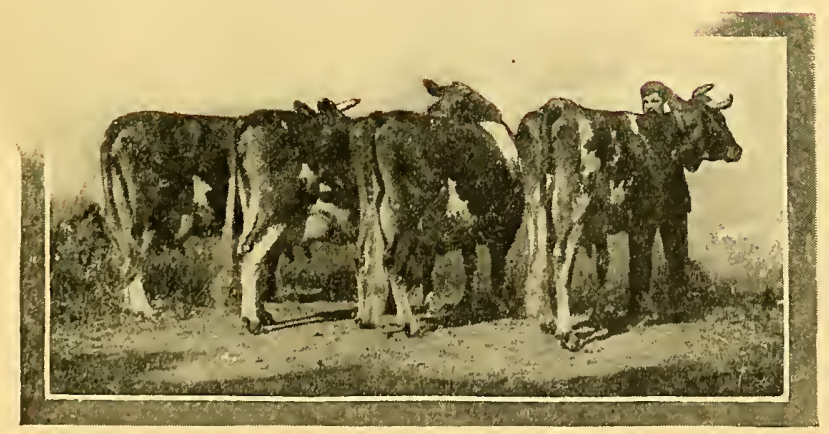


246 I P. S. She was imported from the Island by Mr. Twombly at the same time Clarmante was, and is in markings and conformation a very worthy follower of the latter cow.

She was fresli Oct. Ist, I902, and commenced her record Oct. 5 th. In the following twelve months she gave as follows:

IMP. PRETORIA I 4443. ADK. K. 73.

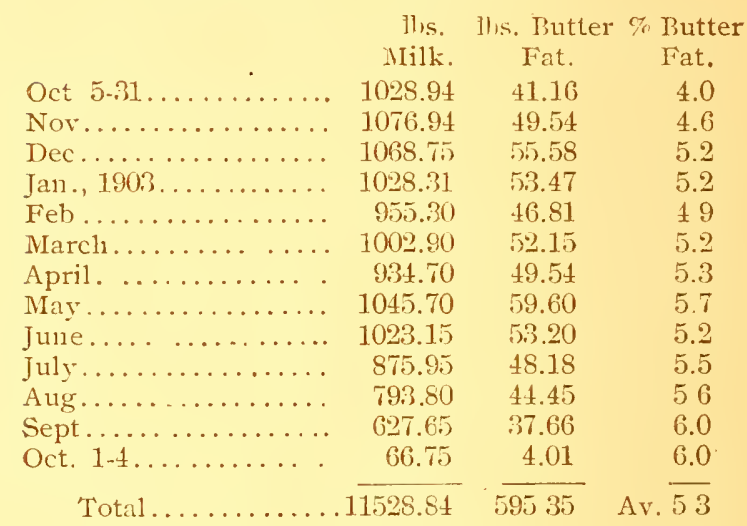

She being filly a year and a half younger than Charmante her requirements for admission were only 9.63I.75 lbs. milli and 350 1bs. butter-fat. She equalled her requirements and also produced enough more to entitle her to third place in the list of official records.

Her management and care was similar to that of Charmante. The rough fodder being the same. The grain fed during the year:

Bran $58 \%$

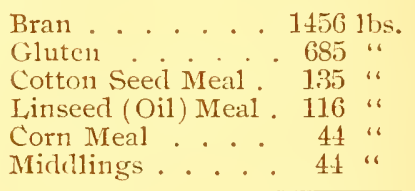

Total . . . 2480 1bs., or 6.79 1bs. daily

This is practically another two-pound-a-day butter record for a year.-The Herd Register and Breeders' Journal.

Thesc are official. What did it? Bran certainly a'as the largest itcm in the concentrates, bcing 58 per cent in cach case. Was this simply a guess on the part of Mr. Hope? We hardly think so. 
Please read the following from Mr. James J. Hill, president, Great Northern Railway Co. :

St. Pazl, Minx., May gtli, igo4. Mr.

WASHELRT-Crosby Co.,

Minneapolis, Minn.

Jas. J. Hill

Gextlemex:-Replying to your letter of the 5th instart, in regard to the use of bran for animal food, I beg to say that I consider wheat bran as the best basis of mi.rture for animal food rations. While its value as food is good, its use adds to the value of other foods by facilitating digestion and assimilation. This applies generally to feeding in all its

Bran the best Basis branches. Iours truly,

(Signed) JAMES J. HILL.

Is this a guess on the part of Mr. Hill? Thy does it have any significance? Simply because it shows that this master-mind adopts all methods that are improvements to anything in which he may be interested, whether it be food for his herd on his splendid farm at Vadnais Park. Minnesota; a new style locomotive; an increased capacity car: or a new mammoth steamer for the Orient. Mr. Hill started in life a poor man: he improved his opportunities: he grasped the situation and torlay is a recognized leader in the railroad and financial world. If he with his great enterprise has time to inok into details and economic conditions of his farm, rion't it pay you to do so.

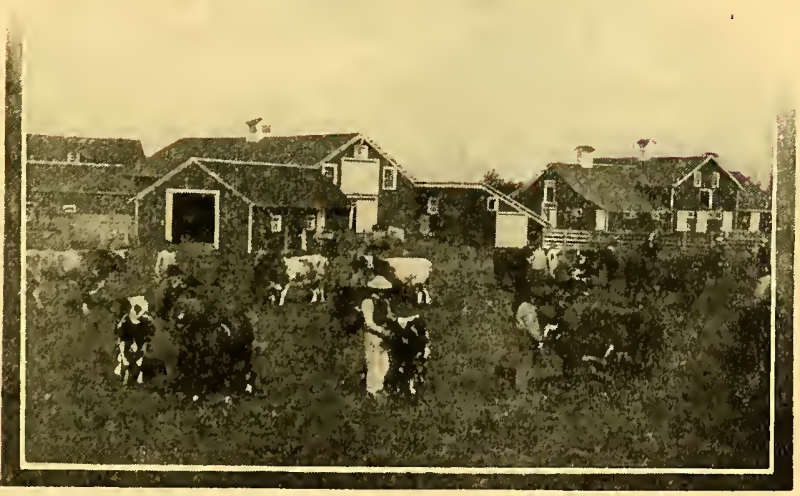




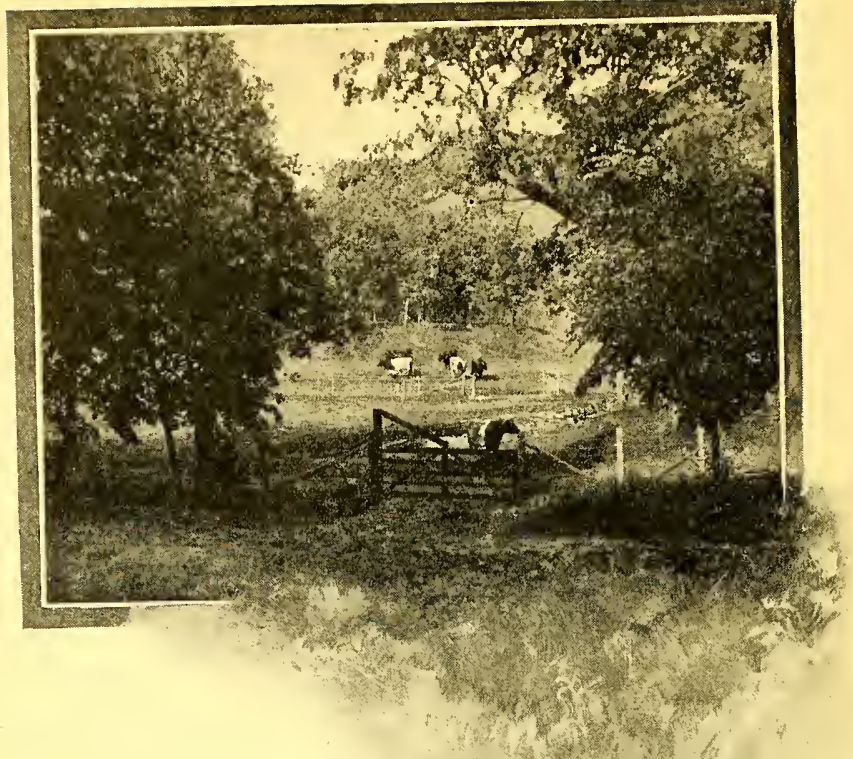

Following is a tetter from Mr. William H. Dunwoody, President of the Northwestern National Bank, also Prestdent of the St. Anthony \& Dakota Elevator Co., as well as Vice President of and Director in a half dozen

Mr.Wm. H. prominent institutions of Minneapolis. He has Dunwoody been eminently successful in. business, and therefore at his Woodhill Farm he feeds his stock on bran-because it is economy and wisclom to do so. Don't you think you better get in line?

Woodhill Farm, Wayzata, Minn. June 24, I904.

Washbura-Crosey: Co.,

Minneapolis, Minn.

DeAR Sirs:-I regard the use of Bran indispensable in feeding either dairy, breeding or fattening stock. In our special case, raising high class

Bran Scotch Sloort Horns, we use it as the basis of all Indispensable of the various rations. The mixture is at times ground corn, oats or barley, and at other times ensilage or roots. In every instance we start with a good proportion of Wheat Bran. Our animals always do well and prove by their condition the value of our method of fecding.

(Signied) WM. H. DUNWOODY, Proprietor Woodhill Farms. 
Agricultural College, Mich, April 7, 1904.

WASHbURN-Crosey Co,

Minneapolis, Minn.

Gentlemen:-I have your letter of the 4 th inst. and beg to reply as follows:

The value of a feeding stuff can hardly be measured by chemical analysis even when that analysis is accompanied by careful digestion experiments. Other factors of supreme importance to be considered in measuring a food beside its chemical composition and its digestibility and ultimate effect of food upon the animal is not measured by its chemical composition and its digestibility alone. The physiological effect of a feeding stuff includes its chemical composition and digestibility and the individual characteristics and peculiar qualities of the food itself, characteristics and peculiarities which cannot be determined by long courses of feeding but whicl after all point out the real values of the material. Wheat bran. formerly despised and rejected, has become almost a cornerstone of dairy feeding. There are feeds that are richer in protein, like cottonseed meal and linseed meal, but none of them possess that peculiar adaptability to the wants of the dairy cow that characterizes wheat bran. Other feeding stuffs, like corn meal and oats, approacls wheat bran in chemical composition and digestibility, but they too lack that peculiar principle that adapts them to the wants of the dairy cow. The long continued experience of dairymen in Wisconsin, Michigan, Iowa, Illinois, New York and Pennsylvania, has increased the just popularity of wheat

\section{Prof. \\ C. D. Smith}

Bran the

Corner-stone 


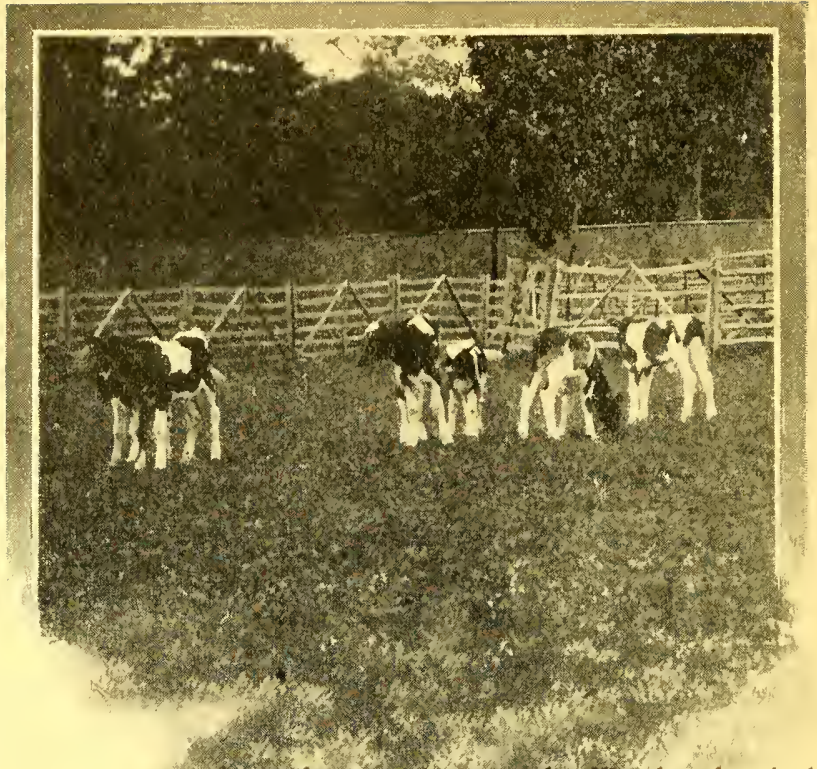

btan becalse it pot any fills the chemical requirements ot heymoun, put pioduces the desired physiological effect thon the cystem of the cow that the dairymen so much desire.

I do not say that a ration cannot be combined of the coarser grains; like corn and oats with clover hay and silage, which will not be eminently satisfactory. I know that such a ration can be combined because

Here is $I$ have succeeded in making up such combinations Economy of them and have found them satisfactory. No claim can be made that wheat bran or any other of the by-products of the flouring mills are indispensable, but it is undoubtedly true that a more satisfactory ration can be made with wheat bran as a basis than can possibly be made without it. A farmer who has corn and oats will seldom find a time when, at current prices, he can afford to feed his oats rather than exchange at least a part of them for wheat bran. For instance, with oots at 320 per bu., he would better sell them and buy bran if he can get it at anytling less than $\$ 24.00$ per ton. He will get his protein cheaper, and besides will get the advantage of the peculiar plysiological effect of the wheat bran itseif.

What is true of wheat bran for dairy cows is true of middlings for pigs and calves. I know that

Middlings theoretically if you are to take the cream from the and Bran milk you should supply its place with something and Bran containing a large per cent of oil, but if you are for Calves feeding young calves I have never found anything better than linseed meal one part, wheat.bran one part, middlings one part and whole oats two parts, as a combination grain feed for calves from four 
weeks old up as long as they are fed skim-milk, the grain feed being fed not in the milk, but separately and dry in a trough and given to the calves as soon as they have finished drinking their portion of the skim-nilk. I have found that the calves take to this combination with avidity, and eating it just after drinking the skim-milk satisfies their natural instinct to suck something. I should hardly know how to bring up calves on skimmilk without bran and middlings. I have tried corn meal ground fine, raw and boiled, but the millfeeds have, in my experience, demonstrated their superiority. For young pigs, too, I know of nothing to take the place of middlings with the skimmilk. Here we add some corn meal, but never feed young pigs on corn alone. I remember trying on my own farm, the feeding of more condensed protein with the corn and skim-milk, but have never had so good success with pigs under one hundred pounds in weight as when $I$ fed middlings two parts and corn meal one part with the skim-milk, and of the two it would be better to omit the corn than the middlings. All through the corn belt, therefore, middlings are practically' indispensable for young pigs.

IVith early lambs, coming in December for the early spring trade to be sold at a weight of fifty pounds or thereabouts, wheat bran is also indispensable. The young lambs are fed in a pen separate from their dams, on a variety of grains, oats, cracked corn, wheat bran and a very little linseed meal with the half of a mangel nailed against the wall for dessert. The wheat bran regulates the bowels of the young

\section{Middlings} Indispensable for Pigs

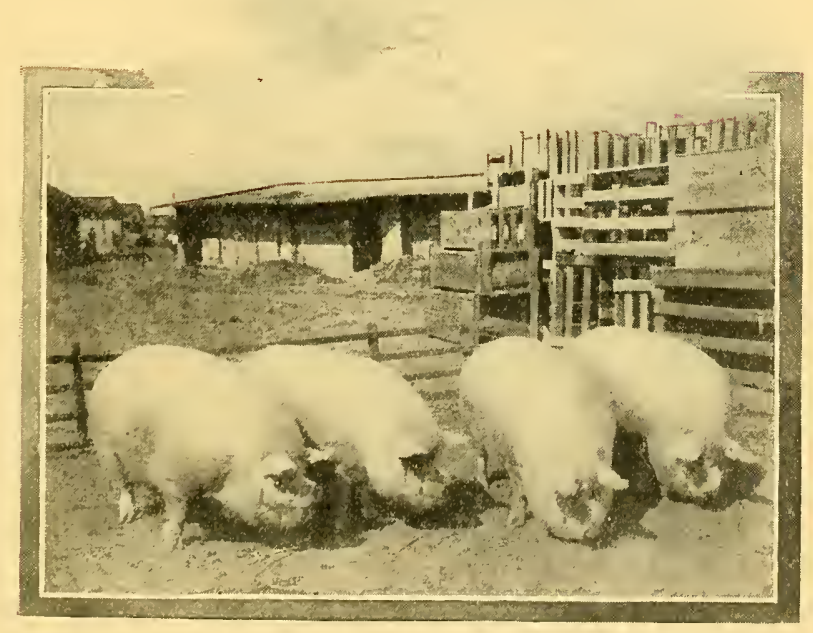




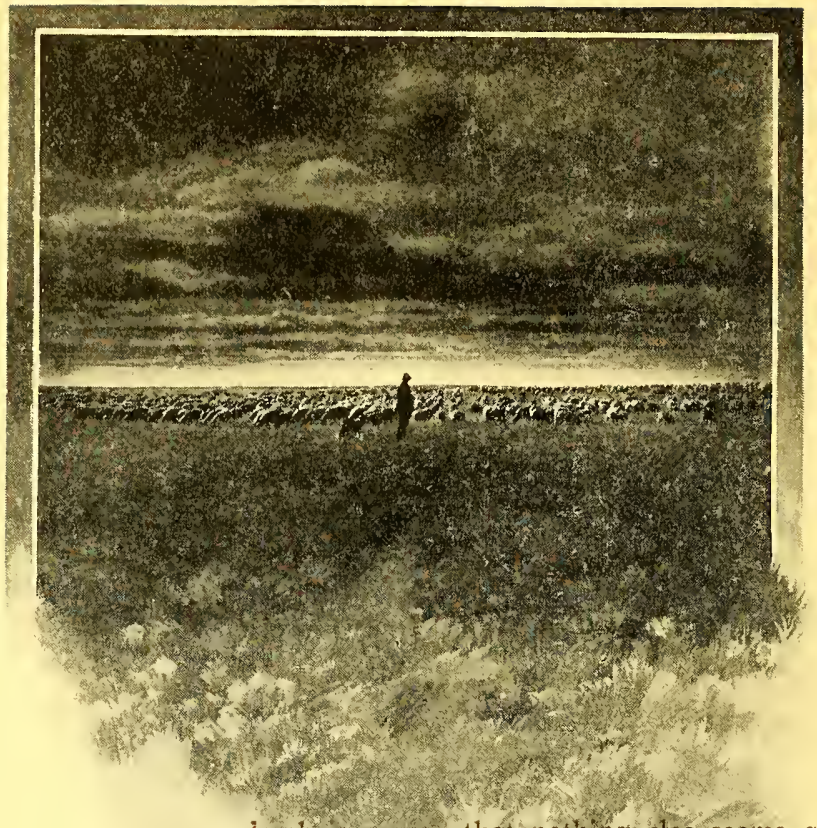

lamb in a way that nothing else seems quite to do. For the mature sheep we can dispense with the bran if we have clover hay and corn. In the absence of clover hay, wheat bran is well nigh indispensable as a bowel regulator where timothy hay and corn stalks form the ration.

My experience with low grade flours is too limited to make my opinion of any value.

Yours respectfully,

$$
\text { (Signed) C. D. SMITH. }
$$

Director Michigan Experiment Station.

College of Agriculture and Agricultural ExPERIMENT Station.

CORNell University.

$$
\text { IтHACA, N. Y., April 8th, '04. }
$$

Mr. W. G. Crocker,

Care Washburn-Crosby Co.,

Minneapolis, Minn.

Dear Sir:-Yours of April 4th, to Prof. Roberts, has been referred to me. It seems hardly nec-

Bran the essary at this late date to say very much in reply to your question. Bran and other wheat by-products, when clean and of good quality, are so standard a food all over the country as to require no testimonials as to their value.

$$
\text { Yours very truly, }
$$

(Signed) H. H. WING, Frofessor of Animal Husbandry. 
Washburn-Crosby Co.,

Wooster, Оhio, April i6th, 'o4.

Minneapolis, Minn.

GENTLEMEN :-Replying to yours of the IIth, I have to say that Wheat Bran seems to be practically indispensable to profitable feeding of cattle. We use it as the basis of all our rations, mixing with it whatever other materials we may desire to use; using it not only for its nutritive value, but for the further value which we believe it has of separating the finer particles of other feeds, thus enabling the digestive fluids to act upon them more effectually. You will see that this last reason for using bran will not apply to other forms of mill feed, and therefore we do not use any other wheat products than bran, preferring corn meal, oil meal, etc., for the completion of our rations.

Yours truly,

(Signed) CHAS. E. THORNE,

Director Ohio Agricultural Experiment Station.

\section{Bran the Basis}

College Park, Prince George Co., Md., April 18, 1904.

WAShidun-Crosby Co., Minneapolis, Minn.

Gentlemen :--In answer to your inquiry of recent date, would say that the great value of Wheat Bran, and all the wheat by-products, as stock food has been demonstrated by numerous chemical analy-

\section{Confirmed by the Cow} ses and digestion experiments, and these results

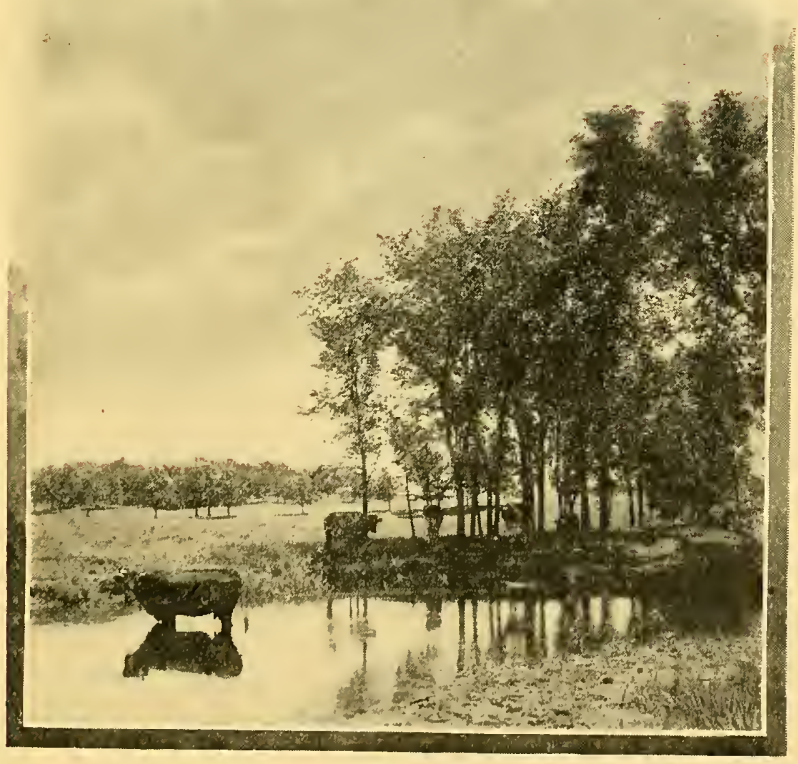




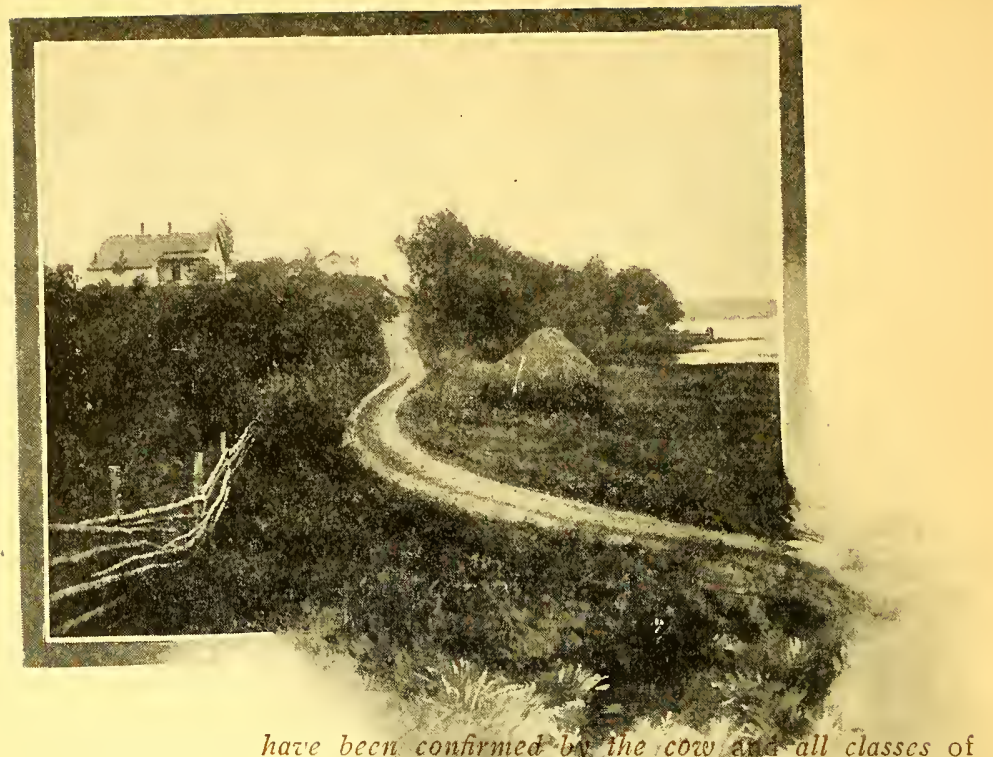

have bect confirmed bo the cow atdall classes of live stock. There wouff seem to be no further or higher evidence refuired to convince allupersons of the merits of these standard feeds

Very truly youts,

(Signed) H. J. PATTERSON,

Director. Maryland Agricultural Experiment Station.

Burlington, Vt., April Sth, ig04.

WASHBURN-Croser Co.

Minneapolis, Minn.

Gentlemen:-Replying to yours of the 5th would say that our idea as to the value of wheat bran is, perhaps, as well expressed by our deeds as by ou1 words. We buy, and have bought for the past ten years, two cars yearly to feed our cows. I should not carc to try to make up a dairy grain ration

Bran always Reliable zeithout including bran as the basis thereof.

Similarly I may say for middlings that we have used these for years in connection with skim-milk in the growing of pork, and believe them eminently adapted to the purpose.

I cannot speak so favorably for the so-called "mixed feed" as I can for either bran or middlings. We do not use it, and are inclined to believe that it is less satisfactory in the long run, taking one brand with another, than is either the straight bran or straight middlings.

Yours truly,

(Signed) JOSEPH L. HILLS.

Director, University of Vermont and State Agricultural College, Agricultural Experiment Station. 
Office of

JoHN H. Albin,

Attorney and Counsellor at Law.

Concond, N. H., April 28, Igo4.

WASHBURN-Crosby Co.,

Minneapolis, Minn.

GenTLEMEN :- Yours of the $22 \mathrm{~d}$ inst. from your Feed Department, asking me to write you my opinion with reference to "feeding values of spring wheat bran and other by-products" is received, and contents noted. I disposed of my farm some ten years ago, and since then have not had occasion to feed, but prior to that time I used to feed large quantities of wheat middlings. I generally mixeid the same. My herd was a dairy herd and I thought that the bran was very valuable for my cows. It insured a good quantity and a good quality of milk, and at the same time, I thought it was a preventive of garget and kindred difficulties with which the dairy Jersey breed was especially apt to be afflicted. I think I never had a case of that kind in my herd of about sixty head unless I could trace it to animals that had been fed on other feed than wheat bran and middlings, or oats. When corn to any extent and other feeds had been used, I found $I$ had to exercise great care to prevent garget, milh ferer and the like.

Yours truly,

\section{J. H. ALBIN.}

St. Anthony Park, Minn., May 5th, Ig04. Mr. W. G. Crocker,

Care Washburn-Crosby Co., Minneapolis, Minn.

My Dear Sir:-Replying to yours of the $4^{\text {th }}$ ult., would say that wheat bran and other wheat by-products in general are held in high favor by all feeders of live stock.

I quote from Director Jordan's work, "The Feeding of Animals," page 228: "No commercial feeding stuffs are regarded with greater favor or are more widely and largely purchased by American feeders than the by-products from milling wheat. Wheat bran and middlings are cattle foods of stand. ard excellence whether we consider composition, palatableness, or their relation to the quality of dairy produce."

Prof. Hecker says that wheat bran is the recognized standard milk food and considering cost there is nothing better.

\section{Prof.Wm. M. Liggett}




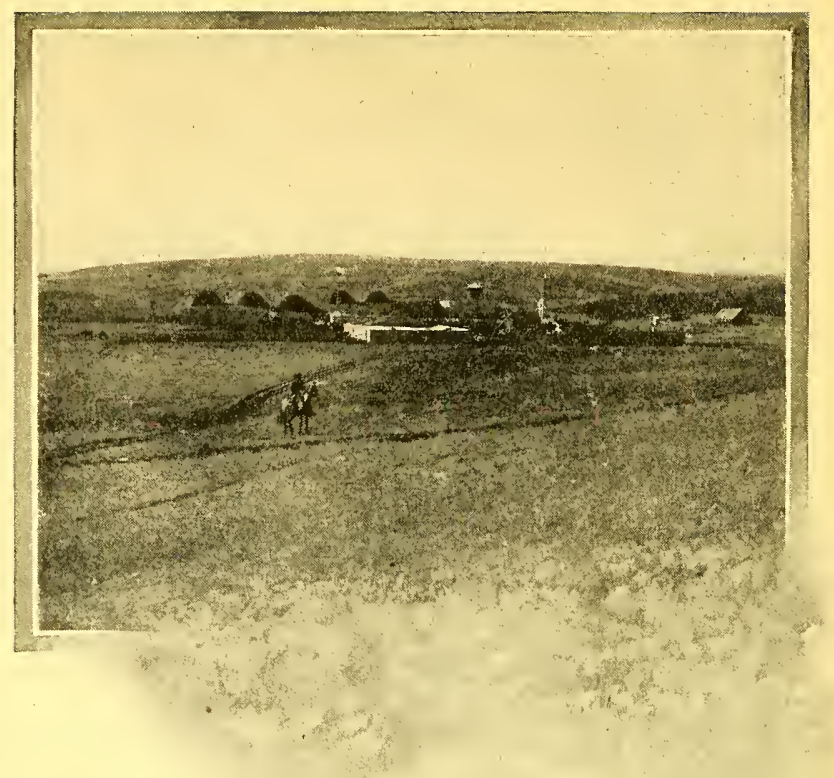

Director Henry of the Wisconsin Experiment Station also speaks in the highest terms of wheat bran as an animal food, and his statements are based largely upon careful personal observation.

Prof. Snyder states, as to the comparative value of wheat bran, corn, oats and other grains: "It is difficult to make a definite statement because of the lack of sufficient data upon. which it can be based. In all the feeding trials which have been made, wheat bran has made a good showing. The chief value from the feeding of bran is undoubtedly secured in feeding it with other foods. Too fre-

Bran also produces valuable Fertilizer quently there is a lack of variety in the grain ration and animals tire of their food." Wheat bran can be combined advantageonsly with any grain or farm product.

The use of bran is not to be measured alone by the amount of milk or meat it will produce. It also produces a most valuable fertilizer. The fertility of the soil needs to be kept up. There is no better way of doing this than by keeping live stock and utilizing all of our mill products, particularly bran, to the best advantage.

Very respectfully yours, (Signed) WM. M. LIGGETT,

Dean and Director, The University of Minn. College and School of Agriculture, Agricultural Experiment Station. 
Mr. W. G. Crocker,

Manager Feed Dept. Washburn-Crosby Co.,

Minneapolis, Minn.

DEAR SIR:-In answer to your favor of the I8th inst., just received. While I have never made a thorough test in the Winter and Spring wheat bran and middlings, I am thoroughly convinced that there is a large difference in same and always purchase Spring wheat bran and middlings, and specify that in all my orders. It is needless for me to add that I like the Washburn-Crosby goods, and when it is possible get your goods, even at a little advance.

I have used the flour made by your company ever since we went to housekeeping, some seventeen years ago.

Yours very truly,

(Signed) LYMAN BLAIR, Prop., Hillside Farms.

\section{Spring Bran \\ Preferable}

Mr.

Lyman Blair

Belfast, Ireland, December 9th, 1903.

Messrs. Washburn-Crosby Co.,

Minneapolis; Minn.

GeNTLEMEN :-In replying to yours of the 27 th ult.

Ireland has been for very many years a stronghold for bran, a higher price often being paid for it than for wheat, so you will see our farmers know

A word from Ireland the worth of bran as a food for cattle.

Yours very truly,

(Signed) MUNSTER, SIMMS \& CO.

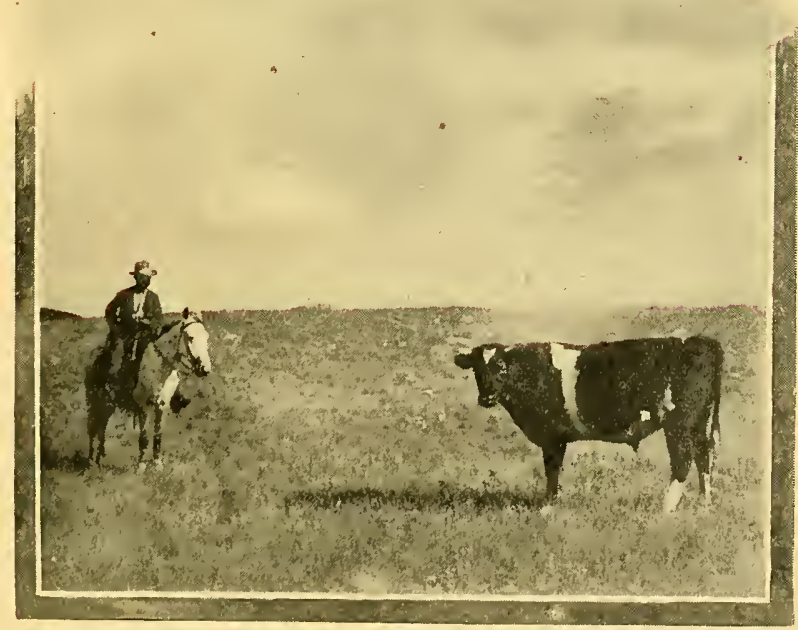


Belfast, Ireland, December 9th, 1903.

Messrs. Munster, Simas \& Co.,

\section{City.}

DEAR SIRS:-Many thanks for the reading of enclosed letter. Evidently your friends are only Another recognizing now what has been known in this word from country for the past thirty years and more, viz: Ireland the good properties of bran as a food for cattle, especially for milch cows. If they come to the United Kingdom market value of this article, they will have no difficulty in selling all they wish to export.

Yours very truly,

(Signed) JAMES MCCAUGHEY \& CO.

New Haven, Conn., April Igth, '04.

Washburn-Crosey Co.,

Minneapolis, Minn.

Gentlemen:-Replying to your inquiry of April I 4th. Bran and other by-products from the

Bran manufacture of flour are standards for dairymen by

measures

efficiency of other Feed
Mr. Frank R. Sanders which they measure the efficiency and value of other feeds. When these wheat feeds are clean and pure they are safe and nutritious, and on most of our dairy farms constitute the basis, and often the larger part of the grain ration.

Very truly yours,

(Signed) E. H. JENKINS, PII. D.

Director Conn. Agricultural Experiment Station.

Laconia, N. II., April 5th, I904.

Washeurn-Crosey Co.,

Minneapolis, Minn.

Gentlemen:-Yours of March 3 ist at hand. I have always advised liberal use of wheat bran in feeding and wheat feeds. We have fed large quantities of your Bran for years, even when nearby farmers valued bran about as much as sazudust. But thcy feed bran now. It should form the basis of all dairy rations, to lighten heavy feeds, and increase the protein content.

Very truly,

(Signed) FRANK R. SANDERS, . Wayback Farm. 
Prof. Henry has been very courteous to us and given us permission to quote freely from his excellent treatise entitled "Feeds and Feeding." We therefore beg to call your attention to the following articles as they appear in this book:

ArtiCle 46. In studying the digestibility of a given feed, the chemist first determines by analysis the percentage of each of the nutrients it contains.

ART. 90. We have learned that the substances which enter the body as food can be grouped under three great divisions: protein, carbohydrates and ether extract.

ART. 98. Taking the experiments here presented and many others by the investigators for guidance, we may conclude that in the exercise of force there is greatly increased expenditure of the non-nitrogenous constituents of the food (carbohydrates and ether extract), and but little of the nitrogenous. At the same time the importance of nitrogenous food must not be under-estimated, for, as Wolff tells us: "No one expects much work from men or animals fed on a dict poor in nitrogen, such as polatocs and ricc. Fatness of body is nerer considered a sign of muscular strength."

ArT. 107. In I884, Samborn, of the Missouri Agricultural Collene, observed more lean and less fat in the bodies of pigs fed ship-stuff (middlings) than in those of pigs fed corn meal. He wrote Does a food rich in carbohydrates and fat tend to pron duce an increased proportion of fat to flesh? I have
Digestibility of Feeding Stuffs

The source of muscular energy

\section{Sanborn's}

Findings

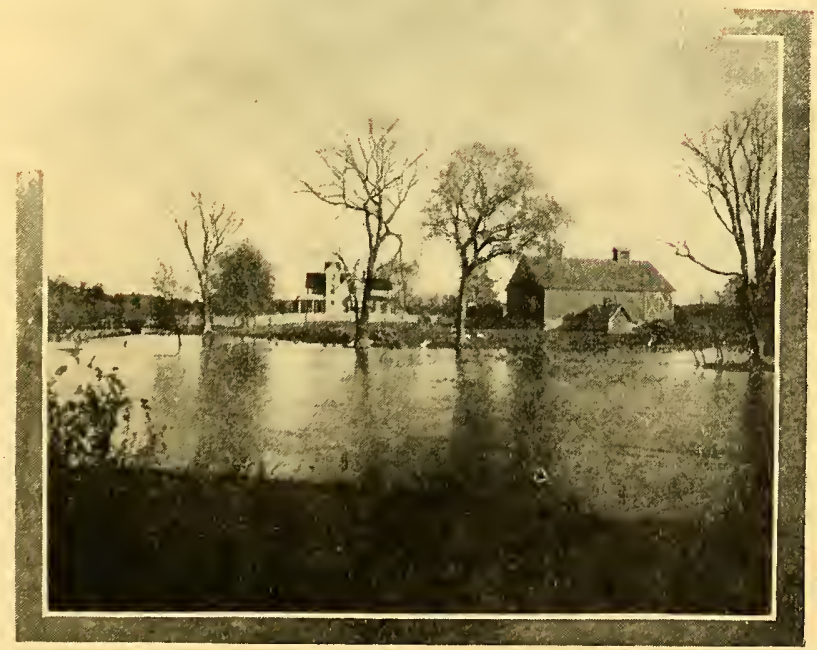




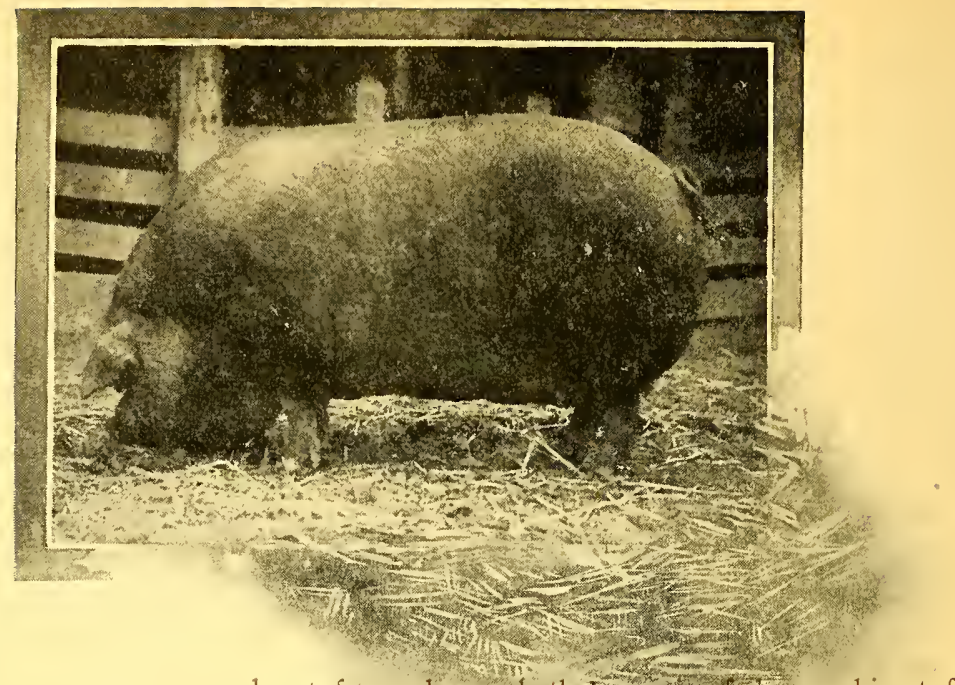

heretofore observed that an pug fed on ship-stuff (middlings) versus com, gave an apparently better muscular development from-ship-stuff. Experience convinces me that the exchuswe use of corn meal for a fecding ration is detrimental to a vigorous and healthy muscular developmerit, producing a piz easily subject to disease, distasteful to our consumers, and more costly than is necessary."

ART. 138. The first attempt to systematically Feeding Table compare various feeding stuffs one with another was by Thaer, who in ISro published a table giving what he termed "hay equivalents."

ART. I39. In 1859 Grouven proposed the first The feeding standard for farm animals, based on the total first Feeding Standard quantity of protein, carbohydrates and ether extract found by analysis in feeding stuffs. This standard fell short of requirements, since it considered the total nutrients instead of the digestible portions.

ART. 143. Feeding standards were first brought to the attention of Americans by Atwater in 1874 , and the efforts of this teacher and investigator have fortunately been continued in the same line to the Introduction present time, greatly to the advancement of scientific of Standards in America agriculture in this country. Armsby's Manual of Cattle Feeding, based on Wolff's book on the same subject, appeared in I8So and marked an area in the educational development of this topic. From these sources the students in our agricultural col. leges, writers and lecturers have come to know of feeding standards, and through them, thousands of feeders have learned to calculate rations for farm animals. 
THEAT AND ITS BY-PRODUCTS IN MILLING.

(Page 1:6.)

- DIGESTIBLE NUTRIENTS AND FERTILIZING CONSTITUENTS.

\begin{tabular}{|c|c|c|c|c|c|c|c|}
\hline \multirow[b]{2}{*}{ Name of Feed } & \multirow[b]{2}{*}{ 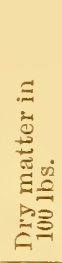 } & \multicolumn{3}{|c|}{$\begin{array}{l}\text { Digestib]e Nutri- } \\
\text { ents in } 100 \text { lbs. }\end{array}$} & \multicolumn{3}{|c|}{$\begin{array}{l}\text { Fertilizing Con- } \\
\text { stituents in } \\
1000 \text { lbs. }\end{array}$} \\
\hline & & 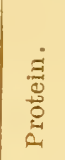 & 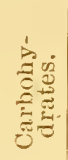 & 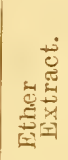 & 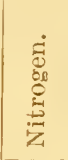 & 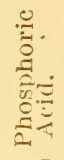 & $\begin{array}{l}\frac{0}{0} \\
\frac{\pi}{0} \\
0\end{array}$ \\
\hline $\begin{array}{l}\text { Wheat ........... } \\
\text { High-grade flour. } \\
\text { Iow grade flour. } \\
\text { Dark feedig flour } \\
\text { Wheat bran...... } \\
\text { Wheat bran. }\end{array}$ & $\begin{array}{l}1 \mathrm{bs} . \\
895 \\
87.6 \\
87.6 \\
90.3 \\
88.1\end{array}$ & $\begin{array}{r}1 \mathrm{bs} . \\
10.2 \\
8.9 \\
8.2 \\
13.5 \\
12.2\end{array}$ & $\begin{array}{l}\text { lbs. } \\
69.2 \\
62.4 \\
62.7 \\
61.3 \\
39.2\end{array}$ & $\begin{array}{l}\mathrm{lbs} . \\
1.7 \\
0.9 \\
0.9 \\
2.0 \\
2.7\end{array}$ & $\begin{array}{l}1 \mathrm{bs} . \\
23.6 \\
18.9 \\
28.9 \\
31.8 \\
26.7\end{array}$ & $\begin{array}{r}\text { lbs. } \\
7.9 \\
2.2 \\
5.6 \\
21.4 \\
28.9\end{array}$ & $\begin{array}{l}\text { lbs. } \\
5.0 \\
1.5 \\
3.5 \\
10.9 \\
16.1\end{array}$ \\
\hline $\begin{array}{l}\text { spring wheat... } \\
\text { "iheat bran, }\end{array}$ & 88.5 & 12.9 & 40.1 & 3.4 & & & \\
\hline $\begin{array}{l}\text { Winter wheat... } \\
\text { Wheat shorts } \\
\text { wheat middlings } \\
\text { wheat screcnings }\end{array}$ & $\begin{array}{l}87.7 \\
88.2 \\
87.9 \\
88.4\end{array}$ & $\begin{array}{l}12.3 \\
12.2 \\
12.8 \\
9.8\end{array}$ & $\begin{array}{l}37.1 \\
50.0 \\
5.30 \\
51.0\end{array}$ & $\begin{array}{l}2.6 \\
3.8 \\
3.4 \\
2.2\end{array}$ & $\begin{array}{l}28.2 \\
26.3 \\
24.4\end{array}$ & $\begin{array}{r}13.5 \\
9.5 \\
11.7^{\circ}\end{array}$ & $\begin{array}{l}5.9 \\
6.3 \\
8.4\end{array}$ \\
\hline
\end{tabular}

ART. I66. Compared with corn, wheat carries a higher percentage of starch, less ether extract and more protein. Thus it more clearly furnishes a balanced ration for farm animals. It follows that this grain meets the requirements of young and growing animals better than corn, a statement which is corroborated by the experience of feeders.

ART. I75. Wheat bran carries, as we have seen, a considerable amount of crude fiber, somewliat resembling straw in this particular. It differs from straw in that the inner surface of the Bran flakes is made up of the aleurone layer of the wheat grain, which is very rich in protein and in addition carries some starch. Understanding its character and composition, we are in a position to male the best use of this abundant by-product in feeding farm stock. With some horsemen bran is fed only occasionally, being supplied once or twice a week in the form of a "mash," made by scalding with hot water, in which case it is a mild laxative and very beneficial. Bran has, however; become a common feed in many well managed stables. At the Stanford horse farm, a few years since, the writer found it being fed in moderatc quantity to horses of all ages, from weanlings to stallions and brood mares. Bran is quite commonly userl in feeding omnibus and cab horses. Hard-worked horses, which have neither the time Wheat Grain

\section{Bran}

Desirable for Horses nor the unergy to digest feeds with much bulk, should 


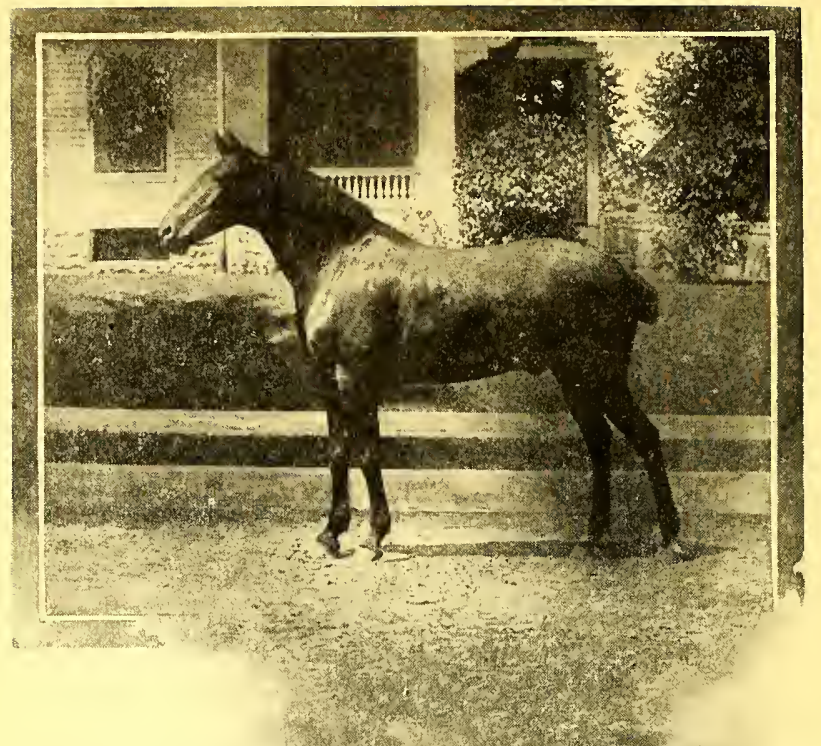

not secele much brat, onmg to its coarse, fibrous character. Growing lorses brood mares and staliions can be fed bran howolly with cxcellent results because of the large amount of mineral matter and protein it contains, its volume not working against it with these anmals. In steer feeding bran serves admirably with eorn in any form. Fed with this grain it gives bulk, supplies protein, and keeps the animal from cloying; as it may when long maintained on a single kind of feed, such as corn. The stockman feeding corn to his steers will find them making better gains and showing: better condition by using bran for one-third of the concentrates. The light character of the bran is well shown in cases of over-feeding. Though a horse or a cow may be gorged with bran, it usually suffers no marked inconverience therefrom, while an over-feed of corn or cotton-seed neal may produce fatal gastric disturbances.

Bran is par cxcellence a leading feed for the dairy cow, furnishing not only bulk, a desirable qual-

Bran par Excellence ity in this case, but protein and ash matter, which are so much needed in the formation of milk. As a complementary food to corn meal, the combination of bran and that grain is not to be excelled. For young pigs bran is too course and straw-like, and middlings should be substituted for it. For brood sows and older animals some bran may be fed with profit, and may prove very useful if the remainder of the ration is to be in concentrated form, for volume is necessary with the feed of such animals. This by-product is also very satisfactory in the sheepyard, being relished by fattening sheep, breeding ewes and growing lambs. 
ART. I-6. We learn from the table (See pag: 263. Table and Article $4 \mathrm{I} 4$ as later appear) that the wireat grain is somewhat richer in nitrogen and mincral matter than corn. The by-products of wheat in milling are much richcr in these particulars than the grain from which they are derized. High-grade flour is not rich in nitrogen or mineral matter. Low-grade flour is rich in nitrogen but low in mineral matter. Dark feeding flour is rich in nitrogen and mineral matter. Bran and shorts carry all the elements of fertility in a large quantity, and for this reason are highly appreciated by those feeders whose interest reaches beyond their cattle to the lands they till. Whien very low in price, bran may be used as a fertilizer by direct application to ihe land, but such perversion should not be tolerated. It should be first fed to animals, and, through their droppings, it will reach the land almost undiminished in fertility.

The great Northwest is now largely devoted to wheat growing. Here the famers are gathering into the wheat grains the fertility which has been accumulating for ages. Prudent farmers and stockmon further east, knowing of the fertilizing ingredients in the by-products of the flouring mills, are making large use of them, and by carefully saving the droppings from their cattle and applying them to the land, are transferring the great fertility of the Northwest to other districts. In this depletion of the soil of the Northwest by almost exclusive wheat growing, and in transferring the fertility taken up by this crop to other regions in the byproducts of milling, we are experiencing one of the greatest economic changes ever witnessed in American agriculture.

ART. 4I3. Phosphoric acid and potash are the two inineral compounds which are not always held by the soil in sufficient quantity to give profitable crops and must be supplied in the form of manure or fertilizers.

ArT. 4I4. The quantity of nitrogen, phosphoric acid and potash found in the various feeding stuffs is given in Table No. 3 of the Appendix. The examples presented below are abstracted from that table for the purpose of illustration:

\section{Fertilizing Ingredients}

\section{Essentia \\ constituents of \\ Fertilizers}




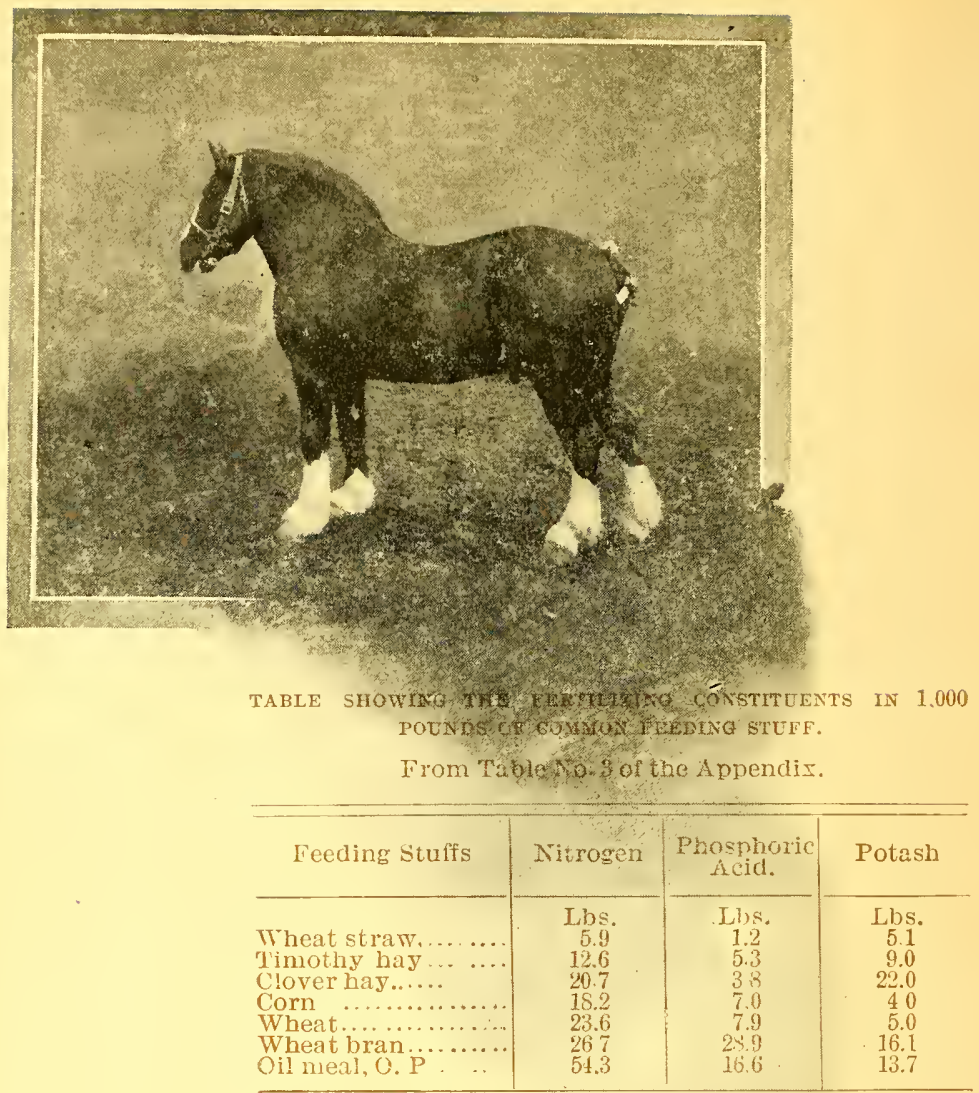

From this table we learin that wheat straw contains 5.9 pounds of nitrogen, and timothy hay more than twice as much, or I2.6 pounds. Clover hay is richer than timothy hay in nitrogen, and especially in potash, thotgh poorer in phosphoric acid. We obscrie a larger quantity of all fertitizing constitucnts, especially phosphoric acid and potash, in wohcat bran than in the wheat grain, from which bran is deriecd. This is because the starchy part of the wheat grain used for flour holds little fertility, while the outside portion of the grain which goes into the bran contains most of the nitrogen and ash.

ArT. 420. The soil in parts of our country is now so depleted that farmers and planters are forced

Commercial Fertilizers to make large tuse of commercial fertilizers in order to sectre remunerative crops. The commercial fertilizers sold in the United States during the year 1896 amounted to $I, 355,000$ tons. Placing a value on these of $\$ 20.00$ per ton, a reasonable estimate, 
we have a total of over $\$ 27,000,000$ paid out by farmcrs and gardeners living mainly in the Atlantic and Gulf states for commercial fertilizers in a single year. For the year $\mathrm{I}_{95} 5$ the farmers of Connecticut expended over $\$ 700,000$, and those in New Jersey $\$ 1,575,000$ for commercial fertilizers.

The market value of commercial fertilizers is based on their content of nitrogen, phosphoric acid and potash. Because of the enormous quantity of fertilizcrs used, each of their three valuable constituents has a definite market value. The average price of these ingredients in the wholesale market is as follows: Nitrogen, I5; phosphoric acid, 7; and potash 4.5 cents per pound. The prices of these articles do not fluctuate any more than do those of other standard articles of commerce.

ART, 42I. If we follow the plan adopted by some Eastern Stations of placing the same values on nitrogen, phosphoric acid and potash in feeding stuffs that these constituents bring when sold in commercial fertilizers, we are in a position to compare the fertilizing values of the several feed stuffs. Wheat bran and corn are compared in the table below:

VALCE OF THE FERTILIZING CONSTITUENTS IN 1,000 POUNDS OF WHEAT BRAN AND CORN.

\begin{tabular}{|c|c|c|c|c|c|c|}
\hline \multirow[b]{2}{*}{ Constituents } & \multicolumn{3}{|c|}{ Wheat Bran } & \multicolumn{3}{|c|}{ Corn } \\
\hline & $\begin{array}{l}\text { ñ } \\
0 \\
\vdots \\
0 \\
0-1\end{array}$ & 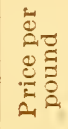 & 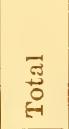 & 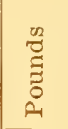 & 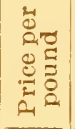 & 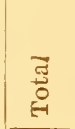 \\
\hline \multirow{2}{*}{$\begin{array}{l}\text { Nitrogen } \ldots \ldots \ldots \ldots \ldots \ldots \\
\text { Phosphoric Äid........ } \\
\text { Potash................. } \\
\quad \text { Total................. }\end{array}$} & \multirow{2}{*}{$\begin{array}{l}26.7 \\
28.9 \\
16.1 \\
\end{array}$} & \multirow{2}{*}{$\begin{array}{l}\text { Cts. } \\
15 \\
7 \\
4.5 \\
\\
\cdots\end{array}$} & $\begin{array}{c}\text { Dols } \\
4.00 \\
2.02 \\
.72 \\
\end{array}$ & \multirow{2}{*}{$\begin{array}{r}18 \\
7 \\
4 \\
\cdots\end{array}$} & \multirow{2}{*}{$\begin{array}{l}\text { Cts. } \\
15 \\
7 \\
4.5 \\
\\
\end{array}$} & $\begin{array}{c}\text { Dnls. } \\
2.70 \\
.49 \\
.18\end{array}$ \\
\hline & & & 6.74 & & & 3.37 \\
\hline
\end{tabular}

From the above we learn that the value of the fertilizing constituents in $\mathrm{I}, 000$ pounds of bran is $\$ 6.74$, and in the same weight of corn one-half as much, or $\$ 3.37$. By do sbling these figures we have the following:

Value of fertilizing constituents in I ton of

wheat bran $\ldots \ldots \ldots \ldots \ldots \ldots \ldots \ldots \ldots \ldots \ldots \ldots \ldots \ldots \ldots$

Value of fertilizing constituents in I ton of

corn

\section{Valuation of Fertilizer constituents in Feeding Stuffs}




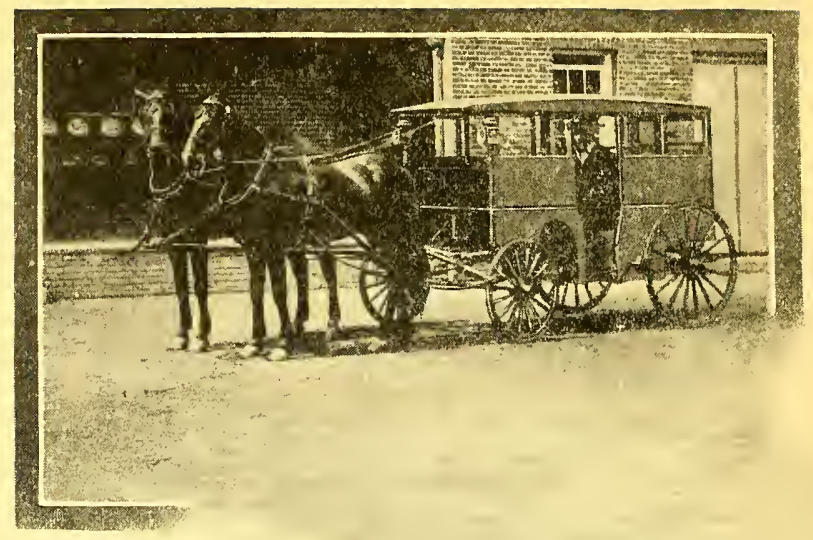

ART. 422. The farmer will ask if it is here taught that he can get returns of $\$$ I 3.48 by the application of one ton of bran to his land as a fertilizer. Such a deduction is not the purpose of these figures. They mean, however, that a ton of bran contains nitrogen, phosplioric acid and potash in such amount that if bought in the form of commercial fertilizers they would cost at least the sum named. They mean that the farmer who harvests a ton of corn and seeks to return to the field the same amount of fertility that was abstracted by this crop must pay not less than $\$ 6.74$ for the requisite fertilizers if bought in the market. Virgin soil as a rule contains a large amount of available fertility, and pioneer farmers, drawing upon Nature's store, give little consideration to the subject. The Western farmer cultivating prairic lands, when marketing corn considers that in so doing he is selling labor and perhaps rent of the land; but rarely does he realize that he is also selling fertility, to replace whicl would cost as much, and often more than the crop bings. The Eastern farmer and Southern planter are now cultivating soils which have been so depleted of available plant food that the subject of fertilizers is a matter of the deepest concern to them.

Art. 42.. It should be borne in mind that the value of farm manures depends primarily upon the

Value of Farm Manure per ton character of the feed given, and, in the second place, tipon the animal to which the feed is stupplied. Manure which originates from the use of concentrated feeding stuffs usually has a high value, because such feeds are rich in nitrogen, phosphoric acid and potash. Manure resulting from the use of straw and coarse forage has a correspondingly low value. 
ART. 463. Shepperd compared bran and oats as a feed for work horses and mules in summer, eight horses and four mules being used. The animals were diviced into two even lots, all receiving good prairie hay for roughage. To one lot was fed oats, while the other received a mixture of bran and shorts, equal parts by weight. The horses averaged somewhat more than seven hours' work per day, the labor being quite severe:

BRAX AND SHOPTS, EQUAL PARTS BY WEIGHT, COMPARED WITH OATS-NORTH DAKOTA STATION.

\begin{tabular}{|c|c|c|c|}
\hline & $\begin{array}{l}\text { Grain } \\
\text { Eaten }\end{array}$ & $\begin{array}{l}\text { Gain or } \\
\text { Loss in } \\
\text { Weight }\end{array}$ & $\begin{array}{l}\text { Work } \\
\text { Done }\end{array}$ \\
\hline $\begin{array}{l}\text { Feeding Bran and Shorts- } \\
\text { Total.equal to } 876 \text { horses one day } \\
\text { Weekly average. per horse....... } \\
\text { Feeding Oats- } \\
\text { Total.equal to } 792 \text { horses one day } \\
\text { Weekly average, per horse. .... }\end{array}$ & $\begin{array}{r}\text { Lbs. } \\
12910 \\
103 \\
11838 \\
105\end{array}$ & $\begin{array}{l}\text { Lbs. } \\
\text { Loss } 10 \\
\text { Loss } 1-12 \\
\text { Gain } 10 \\
\text { Gairi } 1-12\end{array}$ & $\begin{array}{c}\text { Hours } \\
5705 \\
46 \\
4796 \\
42\end{array}$ \\
\hline
\end{tabular}

It is shown that the horses fed bran and shorts ate somewhat less concentrates per week, lost a little in weight, but did three and one-half hours more work per week each than these fed oats. Upon the culhole, bran and shorts proved of equal worth to oats for feeding horses and mules.

ART. 505. Bran has come into general use as part feed for the horse. Shorts or Middlings may be used to the extent of two or three pounds per day.

Art. 544. An experiment is reported from Minneapolis in which the lightest bran made was fed with hay to fifteen common steers for a period of four months. Each animal was fed separately, all feed being weighed. The steers were allowed exercise in a small yard. The steers weighed from 800 to $I, I O 0$ pounds at the time the experiment began in May, r886. The following summarizes the re. sults :

Pounds

Total bran fed ......................... 24,064

Total hay fed ...................... 28,925

Total gain in weight, 15 steers............... 3,545

Average gain in weight (four months)...... 236

Feed for 100 pounds gain ....... $\begin{cases}\text { Bran } & 679 \\ \text { Hay } & 816\end{cases}$

These satisfactory gains show that bran may be successfully used for fattening stecrs.
Bran and

Shorts

compared with

Oats

Feeding the

Work Horse

Bran for

Steers 


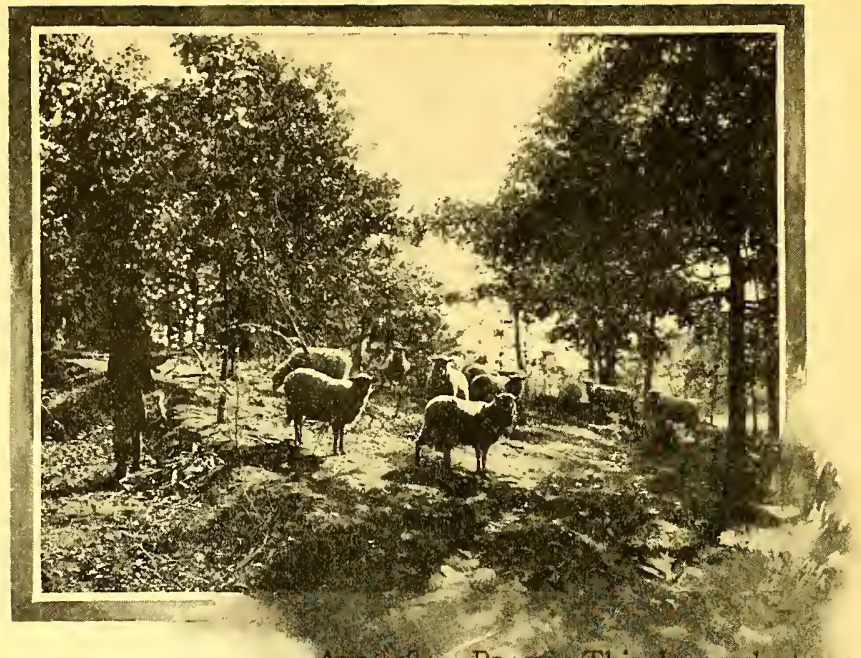

Arr 584-Bran. This byoproduct was at first Bran is regarded with favor-onls by dairynen. Gradually the Bran is steer feeder is learning uts value in connection with Cooling other grain in the feed box. Because of its bulky character and its coous s. slightly laxative properties, bran is a most exedent dilutent for corn meal, cotton-seed meal and other heavy food substances.

Art. 640 (Also cited in Kentucky Bulletin No. 106.) During the years r893-4 extensive feeding trials were conducted by the Copenhagen Experi.ment Station on the estates of dairy farmers. In these trials 447 cows were used. One lot of cows on each estate was fed a mixture of barley and oats; a second was fed one-half wheat bran and one-half grain mixture: while a third lot received wheat bran only. The results briefly summarized were as follows :

FEEDING MIXED GRAIN AND WHEAT BRAN TO 447 DAIRY COWS - COPENHAGEN (DENMARK) STATION.

Wheat Bran compared with Mixed Grain

\begin{tabular}{|c|c|c|c|}
\hline & $\begin{array}{l}\text { Mixed } \\
\text { Grain }\end{array}$ & $\begin{array}{l}\text { One-half } \\
\text { Grain.one- } \\
\text { half Bran }\end{array}$ & $\begin{array}{l}\text { Wheat } \\
\text { Bran } \\
\text { Only }\end{array}$ \\
\hline $\begin{array}{l}\text { Average milk yield per cow. } \\
\text { pounds...................... } \\
\text { A verage per cent solids in milk. } \\
\text { A verage per cent fat in milk.... }\end{array}$ & $\begin{array}{l}21.9 \\
\mathbf{1 1 . 6 6} \\
\mathbf{3 . 0 4}\end{array}$ & $\begin{array}{l}22.1 \\
11.75 \\
3.11\end{array}$ & $\begin{array}{l}22.1 \\
11.77 \\
3.12\end{array}$ \\
\hline
\end{tabular}

These results agree closely, and from them we may assume that wheat bran is of equal feeding value for milch cows with a mixture of barley and oats.

The findings of this test. are of great value because of the large number of cows used in it and fron the further fact that the animals were on various large farms under normal conditions, while all the observations were taken and recorded by Station officials. 
Arr. 719. Next to corm, wheat bran is the great cow feed of this country. Rich in ash and protein, carrying a fair amount of starchy matter, its light, chaffy character renders it the natural complement of heavy corn meal. Though its nutritive constituents approximate those of cotton-seed meal, it mixes well with that feed, causing it to lie more lightly in the stomach.

The large amount of mineral matter in bran is another factor of much importance in milk production. In milk there is much mineral matter, placed there for the frame work of the calf, and bran supplies this more abundantly than most feeding stuffs.

Middlings, like bran, are extensively fed to dairy cows. Being themselves heavy in character, they do not mix well with heavy feeds like cotton-seed meal and corn meal. Dairymen will find middlings much relished by cows and yielding satisfactory returns. Bran and middlings are conceded by all who have fed them to favorably affect the flow of milk.

Cows may be fed as much as six to eight pounds of bran daily and from four to six pounds of middlings.

ART. 854. At the Wisconsin Station, the writer fed three lots of three pigs each on corn meal and middlings, giving the first corn meal, the second middlings, and a third the mixture of the two, equal parts.

At the Missouri Agricultural College, Sanborn conducted two trials with middlings in comparison with corn and corn meal. The results of these trials are summarized below:

\section{Wheat}

Bran and

Middlings

\section{Middlings}


COMPARATIVE VALUE OF MDDINGS AND CORN MEAL FOR PIG FEEDING-WISCONSIN STATION AND MISSOURI AGRIciltURAL COLLEGE.

\begin{tabular}{|c|c|c|c|c|}
\hline Station and Feed & $\begin{array}{l}\text { Dass } \\
\text { fed }\end{array}$ & $\begin{array}{c}\text { Feed } \\
\text { Eaten }\end{array}$ & Gain & $\begin{array}{l}\text { Feed for } \\
100 \text { lbs. } \\
\text { Gain }\end{array}$ \\
\hline 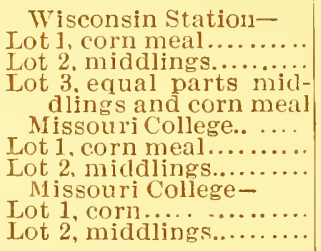 & $\begin{array}{r}42 \\
42 \\
42 \\
116 \\
116 \\
46 \\
46\end{array}$ & $\begin{array}{l}\text { Lbs. } \\
559 \\
501 \\
470 \\
1612 \\
1524 \\
397 \\
334\end{array}$ & $\begin{array}{c}1 \mathrm{hs} . \\
104 \\
96 \\
107 \\
250 \\
252 \\
79 \\
91\end{array}$ & $\begin{array}{c}\text { Lbs. } \\
537 \\
522 \\
439 \\
645 \\
605 \\
502 \\
347\end{array}$ \\
\hline
\end{tabular}

In ihese trials middlings proced superior to corn, Sanborn's second trial showing a remarkably hig! value for this feed. This investigator, commenting on this by-product of wheat milling, writes: "The economy of ship-stuff (middilings) compared with corn has been noted by me every year for seven years, the figures of which are as IO8 to IOO."

The economy of feeding middlings and corn meal in combination instead of separately is shown in the Wisconsin trial, where 439 lbs. of the corrmiddlings mixture proved as valuable as 522 of middlings or 537 of corn meal when fed separately. While middlings were superior to corn when fed alone, a combination of the two proved twenty per cent more economical than middlings alone.

ART. 923. Bran may be fed with good results to breeding stock and to a limited extent to fatten-

One more word about Bran ing swine, the amount in the latter case being restricted, lest the volume of the feed be too much increased. Harris recommends that bran be supplied to pigs in a separate trough, where they can eat it at will. 
BRAN: We have already said much to you on this product and still one-tenth of its goodness has not been told. It will pay you well to investigate Bran and experiment with it as against other feeds. After you have tired of all the rest in this book read the "Bran" part again-it means dollars and cents to you.

SHORTS OR STANDARD MIDDLINGS: This grade is a little heavier than Bran, consisting of fine particles of the Bran, together with a small percentage of Low Grade Flour. It, thereforc, contains slightly more protein than Bran, also a higher percentage of fat. It is an excellent feed to be mixed with Bran for cattle, and is especiallly desirable for fattening young swine.

MIXED FEEDS: This grade is the mill run of Bran, Shorts and Low Grade (or so-called "Ked Dog") Flour. It contains a nigher percentage of protein than Bran, necessarily more expensive, but a very popular feed, and is more of a substitute for an assorted ration. 'This is a comprehensive name, so look out for' imitations. Some of the so-called "Mixed Feeds" offered by the oat meal mills, being mixtures of wheat Red Dog, oat hulls, chaff, etc., are comparatively worthiess and danyerous.

FLOUR MIIDDLINGS: This grade is composed of Shorts and Red Dog Flour, carries a high percentage of protein as well as fat, and is especially adapted to the fattening of swine and young cattle. This name also covers a wide latitude of grades. It is an excellent substitute for corn and its products, and gives more satisfactory results.

RED DOG FLOUR : This grade constitutes the low est class of Flour, is the heaviest feed, contains the highest percentage of protein and fat, and is used chiefly for fattening young swine.
The kind of Wheat Feed and their

Uses 


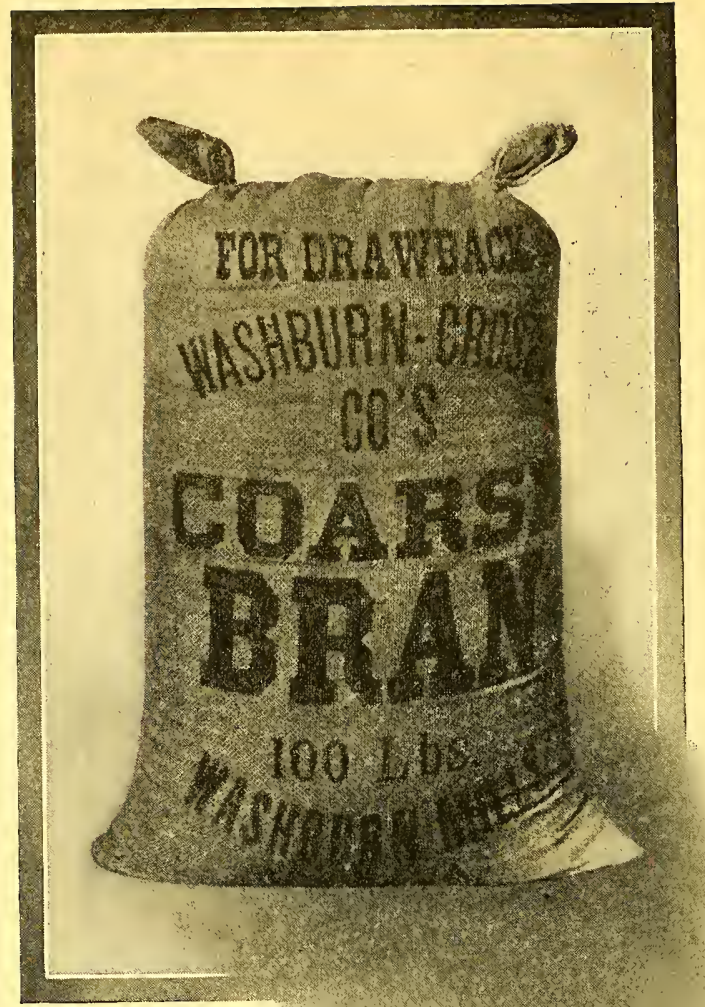

WASHBURN-CROSBY CO 'S MILL FEED. BRAN :

Average Chemical Analyses
Protein ..................... 16.82\%

Carbohydrates.................6.61.64

Ash....................... 642

Fat.................... 4.46

SHORTS:

Protein ................... 19.62\%

Carbohydrates................61.02

Ash....................... . 4.73

Fat....................... 6.28

MIXED IEED:

Protein ............... 18.87\%

Carbohydrates.................60 84

Ash ................... 5.17

Fat................... 5.13

FLOUR MIDDLINGS:

Protein ................. 20.51\%

Carbohydrates.............. 59.02

Ash ..................... 3.90

Fat ..................... 5.80

RED DOG:

I'rotein .................21.06\%

Carbohydrates ..............60 6011

Asl...................... 338

Fat................... 6.16 
it is easy to answer the question, Why Use Bran?

Because, considering its merits, it is the cheapest concentrated food on the market.

Because it is an aid to digestion.

Because of its high fertilizing qualities. The United States Census Bureau showed

Why

Use Bran? that in 1900 there were 5,737,362 farms in the United States, and that in 1899 there was paid out for commercial fertilizers $\$ 54,783,757$, or $\$ 10.00$ per farm. Stop buying these commercial fertitizers and feed more Bran. Its manurial value is worth $50 \%$ of its cost in the Eastern states and $75 \%$ in the west.

Because it is pure and palatable.

Because experience proves that it is a paying proposition.

Because the best authorities advise its use.

Because the most practical feeders use it.

Because Agricultural Experiment Stations will tell you that it slould constitute ain important part of the food ration.

DON'T TAKE

OUR WORD

FOR IT,.BUT STLDY THE BULLETINS.

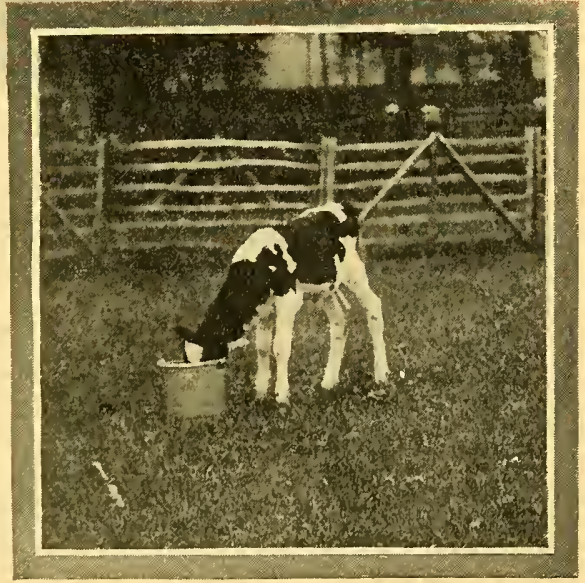




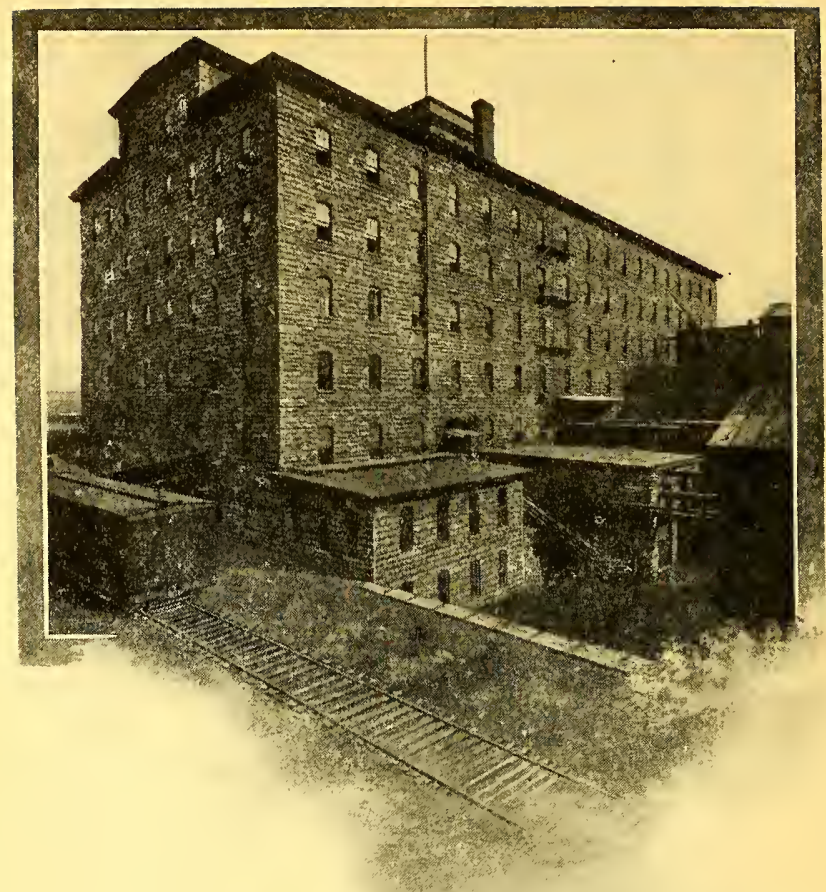

WE HAVE nearly finished, but we want to add a few more facts. We have spoken of the cow, the man, the food, and now just a word about the Great Mills that produce this feed.

Washburn-

Our plant is the largest and most perCrosby fect in the world; our capacity being greater A Mill than that of any other Milling Company; 11amely, 37,000 barrels of flour per day, which means an output of 2,590,000 pounds of Mill Feed per day. Inconceivable as this may seem, it is not bombast, but actual fact.

To make this amount of flour and feed requires 175,750 bushels of wheat each 24 hours and 500 cars to handle the products in and out of our inills. Were our goods not of the very highest quality we certainly would not need so large a capacity to care for our constantly increasing trade. 
If you are not already using our flour you are missing one of the luxuries of life, and if you are not buying WashburnCrosby Co.'s different grades of Mill Feed you are not getting the best value for your money. We candidly admit that we are anxious for your patronage and in return we promise to give you full value received. Remember, please, that every package of our feed bears our full name, "Washburn-Crosby Co.," and is pure, sweet anc fresh ground.

Also kindly bear in mind that you want the genuine article. Do not be satisfied with brands which your dealer may say are "just as good." If they are just as good, get the original and take no chances. This is inportant, and let us, therefore, caution you again to be sure that "WasliburnCrosby Co." appears on the package.

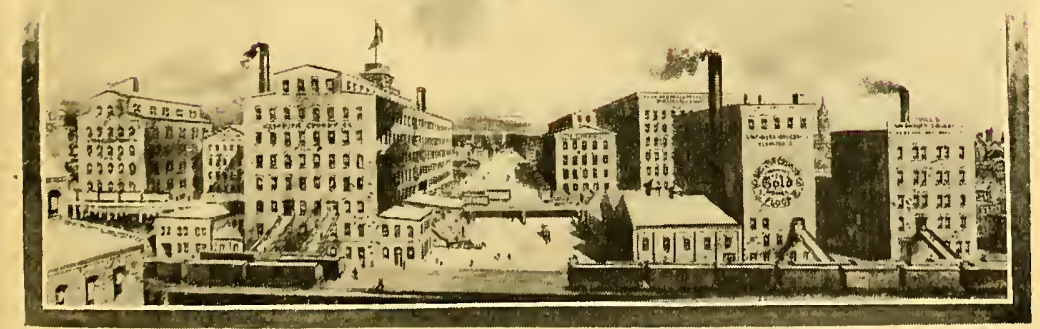




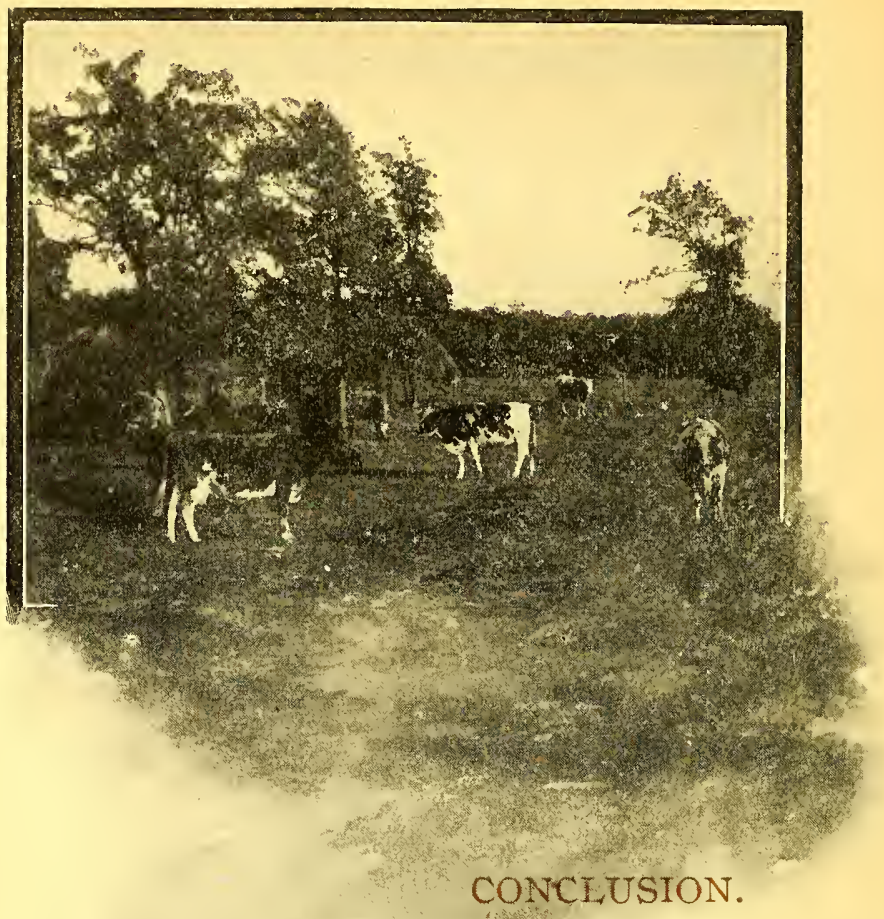

WHHICE the great Minneapolis Mills are producing $16,000,000$ barrels of flour per annum for man, incidentally they are turning out about 1,120,000,000 pounds of feed for beast. I. Volumes have

Remember been written about Washburn-Crosby's flour This and its merits. It is known in every civilized comer of the globe and is shipped to every country on the face of the earth. The by-products (which are abo11t $30 \%$ of the wheat) constitute what might be called an independent industry. As man cannot live by bread alone, neither can beast live on hay alone; that is, to secure the best results.

About fifty years ago English feeders realized the importance of wheat by-products as a valuable feed for the dairy cow and stock in general. Economic condi- 
tions made it necessary for him to feed his cattle on scientific principles. As our own country developed we took the cue from good old Enigland, and about twenty years ago Agricultural Experiment Stations were established in the Eastern States. These have grown until nearly every state in the Union is making a study of everything pertaining to the farm. Nothing has done more to show the value of wheat feeds than these same colleges.

It is now an acknowledged fact, that to secure the best results from a herd Bran must be a valuable portion of the feed ration, and used continually. Bran is as necessary to the farmers barn as bread is to his table.

This commodity, on account of its constituents, is the cream of feed for the dairy cow; containing a much higher percentage of protein than general farm feed. It is clean, pure and highly digestible; and, on account of its coarseness and bulk, is desirable as a vehicle in feeding the more concentrated feeds which the farmer may deem advisable to give from time to time, such as Cotton-Seed Meal, Oil Meal, Corn Meal, etc., too heavy in themselves to feed alone. In this connection it is also an excellent ration for horses.

The heavier grades of feed and Red Dog are especially adapted to the fattening of cattle and swine; being more desirable in some ways than corn or its products.

During the high prices two years ago many Eastern farmers used substitutes cheaper in-price, but found to their regret that it was false economy. 
Incidentally, the experiments at the Agricultural Stations prove the superiority of Spring over Winter Wheat Feed.

It is 110 a fact, fully established, that the feeder or dairyman who tries to do without Bran and the other grades of Mill Feed is being seriously handicapped. The lay feeder never stops to discriminate, or even consider the fact that one kind of feed is not as good as another. His father and his grandfather used mostly corn, oats, barley, and their products. But his progressive brother studies the Agricultural Reports (which can be obtained on application) and makes a decided success of what otherwise might prove a drudgery and an unenviable existence.

In Denmark, the greatest dairy country in the world, Bran is higlily esteemed, supplies being obtained from the Argentine Republic, Russia, England and Canada, and at times within the past few years from the United States.

Thus, in conclusion, it must be readily conceded that while flour is the staff of life for man, wheat feed is the staff of life for beast.

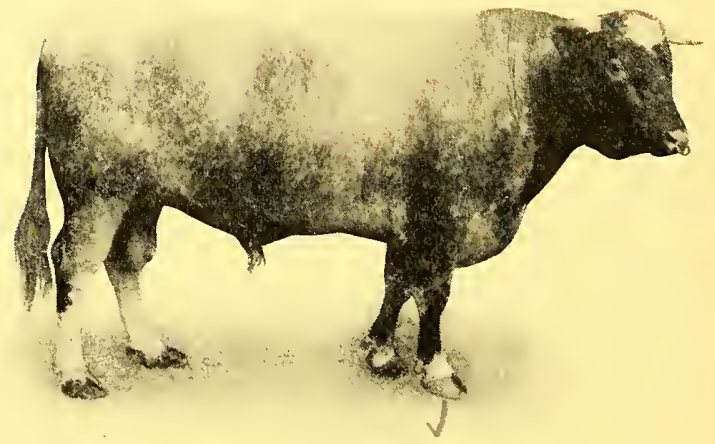





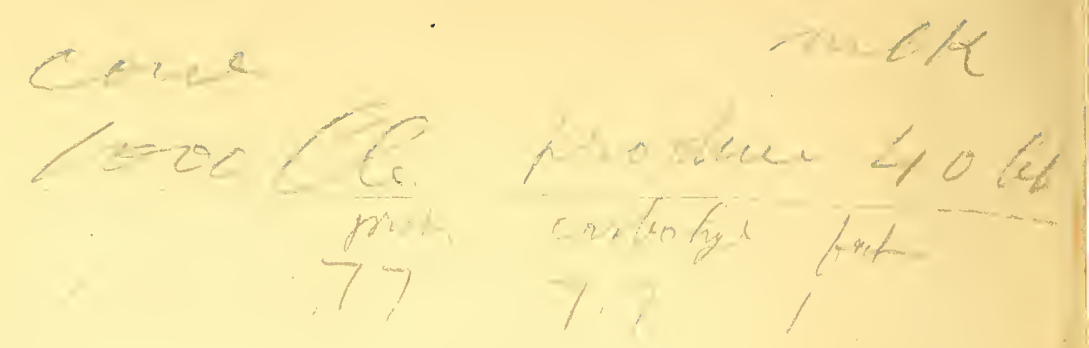





